\title{
A long snout enchodontid fish (Aulopiformes: Enchodontidae) from the Early Cretaceous deposits at the El Chango quarry, Chiapas, southeastern Mexico: A multi-approach study
}

\author{
Jesús Alberto Díaz-Cruz, Jesús Alvarado-Ortega, and Sam Giles
}

\begin{abstract}
Vegrandichthys coitecus gen. et sp., nov., is described in this manuscript based on a single specimen from the Early Cenomanian marine deposits exposed in the El Chango quarry, Chiapas, Southern Mexico. Although this fish exhibits osteological features to support its insertion as a new member of the family Enchodontidae, it has a peculiar combination of characters that includes the presence of a relatively long and stout snout, lateral exposure of the quadrate and mandible articulation, a series of multiple anteroposterior strengthening bars along the opercle, the lateral line running into a series of complex scales, and the anal fin placed behind the dorsal fin. The phylogenetic position of Vegrandichthys was assessed with multiple approaches, namely Standard Maximum Parsimony (SMP), Implied Weighted Maximum Parsimony (IWMP), Phylogenetic Morphometrics (PM), and Bayesian Inference (IB). The single phylogenetic tree obtained from SMP shows the same topology as that resulting from IWMP: Unicachichthys, Veridagon, and Palaeolycus branch successively at the base of Enchodontidae, with the subfamilies Eurypholinae (comprising Vegrandichthys, Eurypholis, and Saurorhamphus) and Enchodontinae resolved as sister groups. The PM performed, including a landmark configuration of the preopercle, suggests that these data contain true phylogenetic signals. In IB, the phylogenetic hypothesis generated retains the clade Eurypholinae, but other taxa are located in a very different topology, which is presumably attributed to the data consistency. Vegrandichthys represents the first formally studied long-snout enchodontid from the Americas. It also was found that the stratigraphic fit of Enchodontidae decreases when Enchodus zimapanensis is included in the analysis.
\end{abstract}

Jesús Alberto Díaz-Cruz. Posgrado en Ciencias Biológicas, Unidad de Posgrado, Edificio A, $1^{\circ}$ Piso, Circuito de Posgrados, Ciudad Universitaria, Coyoacán, Ciudad de México, 04510, México.

vertebrata.j@gmail.com

Jesús Alvarado-Ortega. Instituto de Geología, Universidad Nacional Autónoma de México, Circuito de la

http://zoobank.org/940BA81F-6E6E-427F-80B8-904C620A850E

Díaz-Cruz, Jesús Alberto, Alvarado-Ortega, Jesús, and Giles, Sam. 2020. A long snout enchodontid fish (Aulopiformes:

Enchodontidae) from the Early Cretaceous deposits at the El Chango quarry, Chiapas, southeastern Mexico: A multi-approach study, 23(2):a30. https://doi.org/10.26879/1065

palaeo-electronica.org/content/2020/3063-a-long-snout-enchodontid-fish

Copyright: June 2020 Society of Vertebrate Paleontology.

This is an open access article distributed under the terms of the Creative Commons Attribution License, which permits unrestricted use, distribution, and reproduction in any medium, provided the original author and source are credited. creativecommons.org/licenses/by/4.0 
Investigación S/N, Ciudad Universitaria, Delegación Coyoacán, Ciudad de México, 04510 México. alvarado@geologia.unam.mx

Sam Giles. Department of Earth Sciences, University of Oxford, South Parks Road, Oxford, OX1 3AN, UK. Current Address: School of Geography, Earth and Environmental Sciences, University of Birmingham,

Edgbaston, B15 2TT, UK. s.giles.1@bham.ac.uk

Keywords: new genus; Eurypholinae; maximum parsimony; Bayesian inference; phylogenetic morphometrics

Submission: 9 February 2020. Acceptance: 4 June 2020

\section{INTRODUCTION}

The family Enchodontidae is a monophyletic group of extinct Cretaceous teleost fishes (Fielitz, 2004; Coelho, 2004; Silva and Gallo, 2011), which show a great morphological disparity in the shape of the trunk and snout, and range from between a few centimeters to over one and half meters in length (Díaz-Cruz and Alvarado-Ortega, 2017, 2018). These active and fast predatory fishes inhabited the mid-trophic level and were important components in the trophic chain in the Cretaceous seas, evidenced by their relatively common occurrence as well-preserved gut contents in larger fishes and other marine predators such as cephalopods and plesiosaurs (Stewart and Carpenter, 1990; Maisey, 1996; Cavin, 1999; Cicimurri and Everhart, 2001; Cavin et al., 2012; Porras-Múzquiz et al., 2019).

The enchodontids have been known since the first half of the nineteenth century (Agassiz, 1833); however, their comprehensive study only began in the second half of the 20th century. Prior the present, seven enchodontid genera have been identified (Díaz-Cruz et al., 2019b, table 2); these were inhabitants of marine shallow environments in the peripheral and epicontinental seas of northern Africa [Egypt and Morocco (Arambourg, 1954; Bardet et al., 2017; Holloway et al., 2017)], America [Argentina, Brazil, Peru, Mexico, and the United States (Silva-Santos and Salgado, 1969; Goody, 1976; Bogan and Agnolin, 2010; Schein et al., 2013; Gouiric-Cavalli et al., 2016)], Asia [Lebanon, Israel, Jordan and Japan (Uyeno and Minakawa, 1983; Yabumoto and Uyeno, 1994; Chalifa, 1996; Forey et al., 2003; Kaddumi, 2009)]; and Europe [Netherlands, Germany, United Kingdom, Greece, Italy (Goody, 1968, 1969; Cavin et al., 2012; Friedman et al., 2016)]. Goody (1969) explored the evolutionary relationships of enchodontids; however, the first phylogenetic hypothesis of the group was proposed by Fielitz (2004).
The fossil record of enchodontids is noticeably rich and diverse along the Tethys Sea, mainly in its North American and Middle Eastern realms. Silva and Gallo (2007) identified two areas of Cenomanian enchodontid endemism in this region, one located in North Africa and the other in the Middle East. Later, Cavin et al. (2012) claimed that the biogeography of enchodontids was dictated, in part, by vicariant events. In both studies, the origin of enchodontids is attributed to the central-western region of the Tethys Sea. Recently, Díaz-Cruz et al. $(2019 a, b)$ revealed intriguing data that contrasts with such an idea, specifically the presence of early-diverging enchodontid taxa in Mexico.

Although North American enchodontids have been long studied by numerous authors (e.g., Stewart, 1898; Hay, 1903; Green, 1913; Goody, 1976; Wilson and Chalifa, 1989) and their diversity from numerous sites in the United States of America and Canada is well known, Mexico has recently become a very important territory to study these fishes because they have been extracted in numerous paleontological sites ranging from Albian to Maastrichtian age. The first report of enchodontids from Mexico dates back to the 1950s when Maldonado-Koerdell (1956) found remains of these fishes in Turonian limestones exploited in Xilitla, San Luis Potosí, and inside a rocky core drilled near San José de las Rusias, Tamaulipas. In addition, these fishes have been reported from other sites including the Vallecillo quarry (Nuevo León), the Arroyo Las Bocas (Guerrero), the San Jose de Gracia quarry (Puebla), as well as the Las Boquillas, La Mula, Los Pilotes, and Venustiano Carranza quarries (Coahuila), the El Chango quarry and Tzimol (Chiapas), and the Muhi quarry (Hidalgo) (Blanco-Piñón, 1998; González-Barba and Espinosa-Chávez, 2005; Alvarado-Ortega et al., 2006a and b, 2009, 2019, 2020a and b; Giersch et al., 2008; Fielitz and González-Rodríguez, 2010; Porras-Múzquiz and Alvarado-Ortega, 2011; CarbotChanona and Than-Marchese, 2013; Romero- 
García, 2013; Giersch, 2014; Díaz-Cruz et al., 2016, 2019ac; Díaz-Cruz and Alvarado-Ortega, 2017, 2018; among others). The nominal species of the Mexican enchodontids already described are noticeable, because they represent the most ancient record of this group in America, usually include relatively complete and well-preserved fossils, and are among the oldest enchodontids so far known from the Middle East and North Africa regions (Díaz-Cruz et al., 2019a-c). These Mexican enchodontids are Enchodus zimapanensis Fielitz and González-Rodríguez, 2010, from the AlbianCenomanian deposits of the Muhi quarry, Hidalgo; Unicachichthys multidentata Díaz-Cruz et al., 2016, as well as Veridagon avendanoi (Díaz-Cruz et al., 2019b) from the early Cenomanian deposits of the El Chango quarry, Chiapas (Figure 1). Today, a great quantity of partially described specimens from Mexico is deposited in the paleontologi- cal collections of this country, waiting to be accurately studied.

The aim of this paper is to describe a new genus and species of enchodontid based on a single well-preserved specimen recovered from the early Cenomanian strata of the El Chango quarry, Chiapas, southern Mexico. In addition, the phylogenetic relationships of this new taxon are evaluated under different phylogenetic approaches and the stratigraphic congruence of the family is assessed.

\section{The El Chango Quarry}

El Chango quarry is a small outcrop of laminated limestones and dolomites with sporadic flint nodules located at $16^{\circ} 34^{\prime} 14.9^{\prime \prime} \mathrm{N}$ and $93^{\circ} 16^{\prime} 12.7^{\prime \prime}$ W, within Ocozocoautla de Espinosa Municipality, and about $25 \mathrm{~km}$ to the southwestern of Tuxtla Gutiérrez, Chiapas, Mexico (Figure 2). According
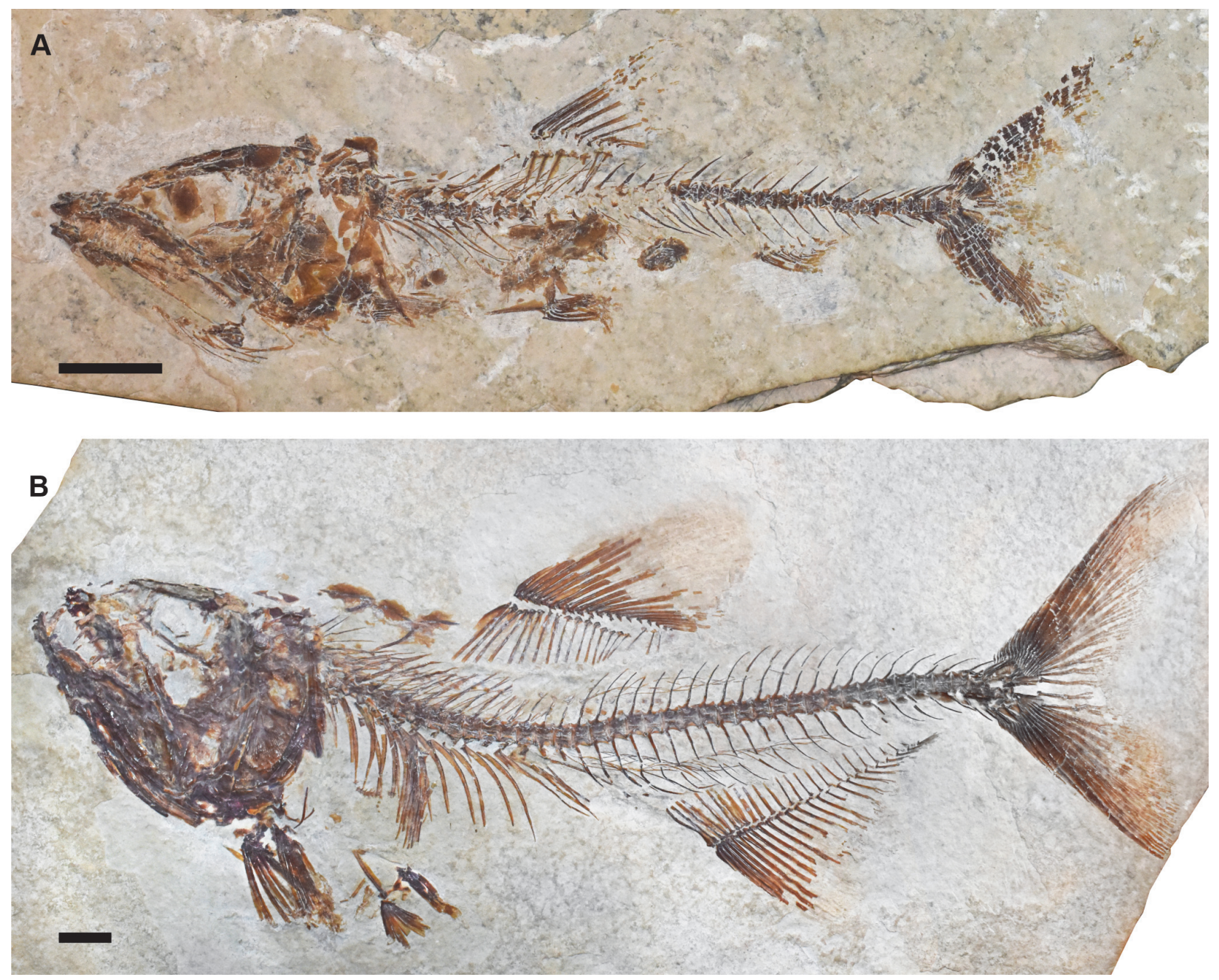

FIGURE 1. Enchodontid species from the El Chango quarry, Chiapas, Mexico; A, IHNFG-2987, holotype of Unicachichthys multidentata; B, IHNFG-5816, holotype and single specimen of Veridagon avendanoi. Scale bar equals 1 $\mathrm{cm}$. 


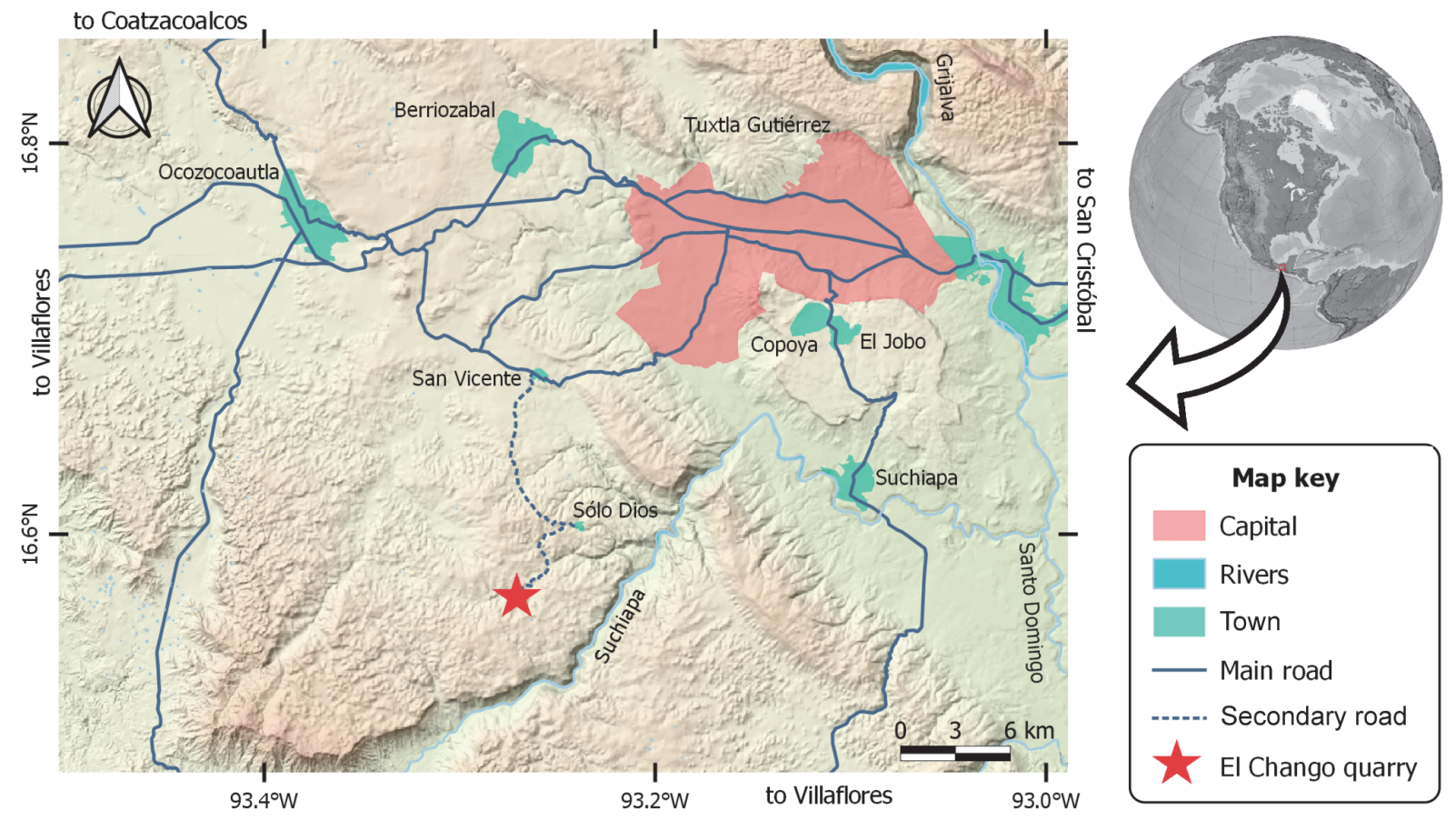

FIGURE 2. Geological map and geographical localization of the El Chango quarry, Chiapas, Mexico.

to Vega et al. (2007) these strata were accumulated in the bottom of an estuarine or salty lagoon with ephemeral freshwater influx during the late Albian; however, subsequently, Alvarado-Ortega et al. (2009) concluded that such age corresponds to the Cenomanian, and later Moreno-Bedmar et al. (2014) stated that this is rather early Cenomanian.

This quarry was opened in 2004 by members of the scientific staff of the Museo de Paleontología "Eliseo Palacios Aguilera" (Díaz-Cruz et al., 2019b). Since then, this institution has been in charge of collecting, studying, and preserving the fossils from this Lagerstätte. Today, the fossil collection from the El Chango housed in this museum contains more than 400 fossils, including mollusks, crustaceans, ammonites, insects, plants, and fishes (Ovalles-Damián et al., 2006; Vega et al., 2007; Alvarado-Ortega et al., 2009; AlvaradoOrtega and Than-Marchese, 2012, 2013; Amaral et al., 2013; Huerta-Vergara et al., 2013; Garassino et al., 2013; González-Ramírez et al., 2013; Guerrero-Márquez et al., 2013; Moreno-Bedmar et al., 2014; Carbot-Chanona, 2015; and Guinot et al., 2019; among others). Fishes are the best-preserved fossils at the El Chango; these are tightly laterally compressed, usually complete and articulated, and often show parts of soft tissues (muscles) and phosphatized stomach contents.
Böse (1905) described the "Cretaceous limestones with rudists" of the Central Chiapas depression, where the El Chango quarry is located, as a Cretaceous platform carbonate series of flint-bearing dolomites and limestones. Although Wiebe (1925) suggested this series as the San Cristóbal Formation; Nutall, in an unedited paper (in Salas, 1949), coined the Sierra Madre Formation name, and this is currently in use. Salas (1949) recognized a natural division of this formation into two units, an Albian-Cenomanian unit of limestones with a sugary aspect and apparently barren of fossils, and a Turonian unit of limestones bearing flints and abundant rudists. Later, González (1963) named these subunits as the Cantelhá and the Jolpabuchil members respectively. The discovery of microfossils during petroleum exploration contributed to re-ordering the units of the Sierra Madre limestones. Although some authors considered the Sierra Madre a single unit (Waite, 1986; Steele, 1986); others (e.g. Sánchez-Montes de Oca, 1969, 1973; Álvarez-Mena, 1975; Quezada-Muñetón, 1987 ) suggested that this geological sequence comprises three formations: the Cantelhá, Cintalapa, and Jolpabuchil formations. Alvarado-Ortega and Than-Marchese (2012) and Moreno-Bedmar et al. (2014) stated that the fossiliferous strata at EI Chango quarry belong to the Cintalapa Formation. 


\section{MATERIALS AND METHODS}

Preparation methods. The specimen studied here was transferred to polyester resin following the process described by Toombs and Rixon (1950, 1959). The bulk of the rocky matrix was mechanically removed using fine pneumatic air scribe; the fossil bones were then totally released from the remaining matrix, with the limestone dissolved through the application of intermittent baths in an acetic acid aqueous solution at $5 \%$ combined with baths in clean water. Pin vises and needles were used to remove the remaining rock residues from the fossil. The fossil was hardened with a light dissolution of plexigum in ethyl acetate applied with a fine brush.

Anatomical nomenclature. The osteological nomenclature and abbreviations used in this paper and its figures follow those used in similar previous publications on enchodontid fishes (Goody, 1969, 1976; Fielitz, 2004; among others).

Institutional abbreviations. IGM, Colección Nacional de Paleontología, Museo María del Carmen Perrilliat, Instituto de Geología, UNAM. IHNFG, Instituto de Historia Natural -Fósil, Geográfico-, housed in the Museo de Paleontología "Eliseo Palacios Aguilera", Chiapas, México. MSNT, Museo Civico di Storia Naturale, Trieste, Italy. NHMUK, Natural History Museum, London, United Kingdom. GMWWU, Geomuseum der WWU Münster. UAHMP, Museo de Paleontología, Centro de Investigaciones Biológicas, Universidad Autónoma del Estado de Hidalgo.

Comparative materials examined. The following specimens were studied for comparative purposes. Cimolichthys lewesiensis Leidy, 1857: NHMUK PV P1810 from the English Chalk, England. Enchodus sp.: IHNFG-2989 and IHNFG-2653 from the Cenomanian deposits of the El Chango quarry, Chiapas, Mexico. Enchodus sp.: IGM 11404 from the Campanian deposits of Ochuxhob, Tzimol, Chiapas, Mexico. Enchodus gracilis (von der Marck, 1858): GMWWU 8428, GMWWU 8429, GMWWU 8494, GMWWU 8498, and, GMWWU 8543 and NHMUK PV P.3848, all from the Upper-Senonian deposits of Sendenhorst, Warendorf, North Rhine-Westphalia, Germany. Enchodus lewesiensis (Mantell, 1822): GMWWU 950 from the Upper Campanian deposit of Darup, Coesfeld, North Rhine-Westphalia, Germany and NHMUK PV P.9249 and NHMUK PV P.73992, NHMUK PV P.9249, NHMUK PV P.5415, NHMUK PV P.4184 from the CenomanianTuronian deposits of Lewes, East Sussex, United Kingdom. Enchodus macropterus (von der Marck, 1858): GMWWU 8427 from the Upper Senonian deposits, Baumberge, Coesfeld, and GMWWU 8426, from the Upper Senonian deposits of Sendenhorst, Warendorf, both from North Rhine-Westphalia, Germany. Enchodus major (Davis, 1887) NHMUK PV P.4763 and NHMUK PV OR.49504 both from the Upper Santonian deposits of Sahel Alma, Lebanon. Enchodus marchesettii (Kramberger, 1895) NHMUK PV P.4748, NHMUK PV P.9250, NHMUK PV P.47315, NHMUK PV P.63181, all from the Cenomanian deposits of Hakel, Lebanon. Enchodus mecoanalis Forey et al., 2003: NHMUK PV P.62522 (holotype) and NHMUK PV P.63250 (paratype) both from the Middle Cenomanian deposits of Namoura, Lebanon. Enchodus longidens (Pictet, 1850): NHMUK PV P.4853 from the Upper Santonian deposits of Sahel Alma, Lebanon. Enchodus petrosus (Cope, 1874): NHMUK PV P. 9647 from the Upper Cretaceous deposits of Kansas, United States. Enchodus zimapanensis Fielitz and González-Rodríguez, 2010: UAHMP 679 (holotype) and UAHMP 678 from the Albian-Cenomanian deposits of Zimapán, Hidalgo, Mexico. Eurypholis boissieri Pictet, 1850: NHMUK PV P.63323, NHMUK P.73, and NHMUK PV P.47313, from the Middle Cenomanian deposits of Namoura, Lebanon. Eurypholis pulchellus (Woodward, 1901): NHMUK PV P.1703 (holotype) from the Cenomanian-Turonian deposits of Lewes, East Sussex, United Kingdom. Palaeolycus dreginensis von der Marck, 1863 GMWWU 808 and GMWWU 8438 (holotype) from the Upper-Senonian deposits of Sendenhorst, Warendorf, North Rhine-Westphalia, Germany. Saurorhamphus freyeri Heckel, 1850: MSNT 7804, MSNT 7805, MSNT 7806, MSNT 7807, MSNT 7809, MSNT 7810, MSNT 7811, and MSNT 7812 from the MiddleUpper Cenomanian deposits of Komen, Slovenia. Unicachichthys multidentata Díaz-Cruz et al., 2016: IHNFG-2987 (holotype), IHNFG-2988, and IHNFG-4347, all from the early Cenomanian deposits of the El Chango quarry, Chiapas, Mexico. Veridagon avendanoi (Díaz-Cruz et al., 2019b): IHNFG-5816 (holotype) from the early Cenomanian deposits of the El Chango quarry, Chiapas, Mexico.

Morphological data set. The assessment of the phylogenetic position of the new taxon described here is based on a morphological data matrix updated from Díaz-Cruz et al. (2019b). In turn, this incorporated data from Fielitz (2004), Fielitz and González-Rodríguez (2010), Cavin et al. (2012), Díaz-Cruz et al. (2016), and Holloway et al. (2017). Our resulting data matrix includes 96 characters and 32 taxa; the modifications implemented in this 
matrix, as well as the detailed description of all the characters, are discussed in Appendix I and II. Our data matrix was generated using the software Mesquite: A modular system for evolutionary analysis $v$ 3.61 (Maddison and Maddison, 2001).

Standard Maximum Parsimony (SMP). Our data matrix (Table 1, Appendix I) was analyzed using the protocols for the Standard Maximum Parsimony available in the program TNT v1.5 (Goloboff and Catalano, 2016). Uninformative characters were deactivated with the command xinact in order to obtain the shortest trees. Deactivated uninformative characters are listed in Appendix II. The outgroup taxon was set as Diplophos Günther, 1873, following Fielitz (2004). All characters were treated as nonadditive (Fitch, 1971). A traditional search (heuristic search) was used with the following parameters: memory up to the maximum number of trees (99999), 1,000 Wager trees as random seeds with 10,000 replications, Tree Bisection Reconnection (TBR) as swapping algorithm and 10 saved trees per replication.

Landmark data. Among enchodontid taxa, preopercle shape is extremely variable; therefore, sometimes this has been discretized in many different character states (e.g., Silva and Gallo, 2011), and incorporated in phylogenetic analyses (see Holloway et al., 2017; Díaz-Cruz et al., 2019b). Inclusion of the morphological variability present in the shape of this bone into phylogenetic analyses is a challenging task; therefore, characters 45 and 91 from the Díaz-Cruz et al. (2019b) related to the preopercle, were re-coded in the current analysis. In addition, a Phylogenetic Morphometrics analysis was conducted using landmark data of the preopercle and SMP analysis combining the landmark data with the morphological character matrix. These analyses are based on photographs directly obtained of the specimens referred above except for the following cases: a) Enchodus dirus (Leidy, 1857) and E. gladiolus (Cope, 1872) (photographs available in the Oceans of Kansas website maintained by Mike Everhart (http://oceansofkansas.com/Enchodus.html); b) Parenchodus longipterygius Raab and Chalifa, 1987 [Raab and Chalifa (1987, fig. 3:720)]; c) Alepisaurus ferox Lowe, 1833 [Goody (1969, fig. 79:172)].

A total of 20 type II and III landmarks [see Palci and Lee (2019) for further details] were obtained from the preopercle configuration using the program tpsDIG 2.16 and tpsUtil (Rohlf, 2005). The .tps file was then edited in Notepad, and taxa lacking preopercle information were filled with the corresponding number of missing entries. Then, the .tps file was imported into TNT 1.5 (Goloboff and Catalano, 2016) to create a readable file (see Table 2, Appendix I). Finally, the matrix was verified to see if the question marks corresponded with the taxa where the preopercle is partially preserved.

Phylogenetic Morphometrics (PM) analysis. The PM analysis was carried out exclusively with preopercle landmark data using the software TNT 1.5 (Goloboff and Catalano, 2016) (Table 2, Appendix I). Before running the analysis, the landmark information was standardized (Imark rescale $={ }^{*}$ ), and the standardization factor set to one (Imark fact=1) in order to calculate the score as the sum of landmark displacement for a single configuration. Then, landmarks were realigned; the method of resistant-fit-theta-rho analysis (RFTRA) for the superimposition of the landmark configuration was used, selecting Cimolichthys as the reference taxon (Imreal rftra [1] /0). Posteriorly, the size of the configurations was modified (Imreal rftra [0]!). The RFTRA method was chosen because, unlike other methods, it uses repeated medians, is less sensitive to the outliers, and accepts missing data in the configurations for the superimposition (Siegel and Benson, 1982; Catalano and Goloboff, 2012, 2018). In the analysis where only the preopercle configuration was analyzed, we verified that only individual landmarks were assessed (Imark noconfsample) to calculate the Bremer support and absolute frequencies for resampling. The rest of the landmark optimization options were left as default in TNT. The designated outgroup for this analysis was Alepisaurus, following Fielitz (2004) and Davis and Fielitz (2010). The strategy of search used in this analysis was the same as that designated for the SMP and IWMP analyses.

A SMP analysis was performed with a combined matrix of landmark and discretized morphological character data (See Table 3, Appendix I). As with the SMP analysis only considering discrete morphological characters, uninformative characters were deactivated (xinact). The outgroup was Diplophos as stated above. The deactivated characters were the same as those in the SMP analysis and can be accessed in the Appendix II. The parameters for the morphological characters were the same as in the SMP and IWMP analyses, and the parameters for landmarks followed those of the PM exclusively with landmarks, except for calculation of support values, which were calculated sampling the entire configuration (default option; Imark confsample). Although the landmark configuration mirrors the contour-line of the preopercle, no dis- 
crete characters related to the preopercle were additionally deactivated or deleted. We made this exercise in order to explore the effect of landmark data addition to the discrete data set, being aware that an overemphasis and/or redundancy of characters might affect the tree topology.

Implied Weighted Maximum Parsimony (IWMP). This exercise uses the new matrix of only discrete characters herein proposed (Table 1, Appendix I). The analyses ran twice, evaluating two different constants: $k=10$ and $k=100$. Each analysis used $a$ traditional search in TNT (heuristic search) with the parameters as described for the Standard Maximum Parsimony analysis.

Bayesian Inference analysis. The $\mathrm{BI}$ analysis was also based on the new matrix of discrete morphological character (Table 1, Appendix I). This analysis was performed using RevBayes v.1.0.10 (Höhna et al., 2016). The Mk script for tree inference with discrete morphology available at https:// revbayes.github.io/tutorials/morph/ was selected. We chose this script as uninformative and invariant characters were left in the matrix (See Appendix II), so correction for ascertainment bias was not necessary. Some parameters of the script were modified to fit the data matrix: 1) the set-up outgroups were the taxa Diplophos and Myctophum as suggested by Fielitz (2004); 2) the binary morphological substitution model was modified to include a five states character Q-matrix, as this was the maximum number in the data set; and 3 ) the number of generations in the MCMC increased to $1,000,000$. The posterior distribution of phylogenies was summarized computing the Maximum a Posteriori (MAP) phylogeny. The MAP tree, according to Höhna et al. (2017), is interpreted as the most probable tree to have been generated based on the observed data. Tracer v 1.7.1 (Rambaut et al., 2018) was used to analyze convergence as indicated by the Effective Sample Size (ESS).

Character mapping. The mapping of characters was carried-out exclusively with the results of the SMP analysis. In TNT 1.5 (Goloboff and Catalano, 2016) we mapped the common synapomorphies to the most parsimonious trees obtained (apo >), and then contrasted with the mapping of synapomorphies in Winclada-ASADO 1.61 (Nixon, 2002) using all characters as nonadditive and showing unambiguous changes only.

Stratigraphic congruence analysis. The stratigraphic congruence of Enchodontidae was assessed with the R package strap (Bell and Lloyd, 2015a). The ages for the stratigraphic calibrations were taken from Díaz-Cruz et al. (2019b:282). In this exercise, only the fossil taxa derived from the SMP analysis were considered, and Cimolichthys was designed as the outgroup because of its close relationship with Enchodontidae (Fielitz, 2004; Beckett et al., 2017). As noticed by Cavin et al. (2012), Enchodus zimapanensis has a derived position in Enchodontidae (see Fielitz and González-Rodríguez, 2010) but is one of the stratigraphically oldest species. Due to this, we analysed stratigraphic congruence twice: first including E. zimapanensis, and secondly excluding it. The number of input trees was one and 38, respectively. The stratigraphic congruence analysis consisted of 1000 permutations with random dates for the tips. Polytomies were treated as soft, tree shape topology as the input, with the same outgroup for all the random trees (hard=FALSE, randomly.sample.ages $=T R U E, \quad$ samp. perm $=1000$, rand.perm $=1000$, fix.topology=TRUE, fix.outgroup=TRUE). We chose the Stratigraphic Consistency Index (SCl) (Huelsenbeck, 1994) as stratigraphic fit measure for the input tree (best $\mathrm{SCl}$ ) and plotted against the ICS 2019 (userdefined). Finally we printed the distribution histogram of the input and randomly generated trees with the $\mathrm{SCl}$ measurement (hist(X\$rand.permutations[, "SCI"]). More detailed specifications are given in Bell and Lloyd (2015b). The second analysis ran with the same specifications.

\section{RESULTS}

\section{Systematic Paleontology}

\author{
Order Aulopiformes Rosen, 1973 \\ Family ENCHODONTIDAE Woodward, 1901 \\ Subfamily Eurypholinae Fielitz, 2004
}

Diagnosis (emended). The species included in this subfamily have slightly to very long bodies as well as slightly to very large snouts; ventral portion of the cleithrum widens anteriorly and posteriorly; cleithrum ornamented with tubercles; ventral border of the mandible straight up to the mandibular symphysis; trunk naked except for the predorsal scute series extended between the dorsal fin base and the occiput and a single lateral scale series that encloses the lateral line.

Genus Vegrandichthys gen. nov. zoobank.org/E9C1E809-0BAC-4822-AD5F-A1F4A7CAA567

Type species. Vegrandichthys coitecus sp. nov., see below.

Etymology. The name is a combination of the Latin adjective 'vegrandis' that means small, and the Greek suffix 'ichthys' or fish. 
Diagnosis. As for the type species, see below.

Vegrandichthys coitecus sp. nov.

zoobank.org/9CDD4D86-98BE-46BC-B19C-7018293E3350

Holotype. IHNFG 5927, an almost complete fish transferred to polyester resin, which exposes the left side of the body (Figures 3-6).

Locality and age. Early Cenomanian laminated limestones of the Cintalapa Formation exposed in the El Chango quarry, Ocozocoautla de Espinosa Municipality, Chiapas, southeastern Mexico.

Etymology. The species epithet is in reference to the word 'coiteco', which is the local given name to the people from Ocozocoautla de Espinosa Municipality.

Diagnosis. Long-snout fish with a moderately elongated trunk; head length almost one third of the body length; small stout ventroposterior spine on the preopercle; large ventroposterior spine on the cleithrum; articulation between the quadrate and mandible laterally exposed; many lateral thickened ridges on the opercle; tiny pelvic fin in subabdominal position; predorsal scutes series consisting of four large and ovoid scutes that are intensely ornamented with tubercles and bearing a medial longitudinal keel; and lateral line scales triangular, smooth, and bearing a prominent medial keel.

\section{Description}

Measurements and general proportions. IHNFG 5927, holotype and only known specimen of Vegrandichthys coitecus gen. et sp. nov. is a gracile, small, and almost complete specimen, in which the entire caudal fin and postanal preural vertebrae are missing (Figure 3A). Table 1 summarizes the measurements and body proportions of this specimen. The standard length in this fish is unknown; however, this feature can be estimated as the length of the preserved part in this fish is $50 \mathrm{~mm}$ and the postanal region of the trunk ranges between a fifth to a seventh of the standard length in other members of Eurypholinae, Eurypholis, and Saurorhamphus (see Goody, 1969, figs. 47 and 55). Based on these data, the estimated standard length of IHNFG 5927 is between 59 and $61 \mathrm{~mm}$.

The head length $(\mathrm{HL})$ is $19.6 \mathrm{~mm}$ and probably represents 32 to $33 \%$ of standard length. The orbital and postorbital regions of the skull show the same length and together represent $40 \%$ of the
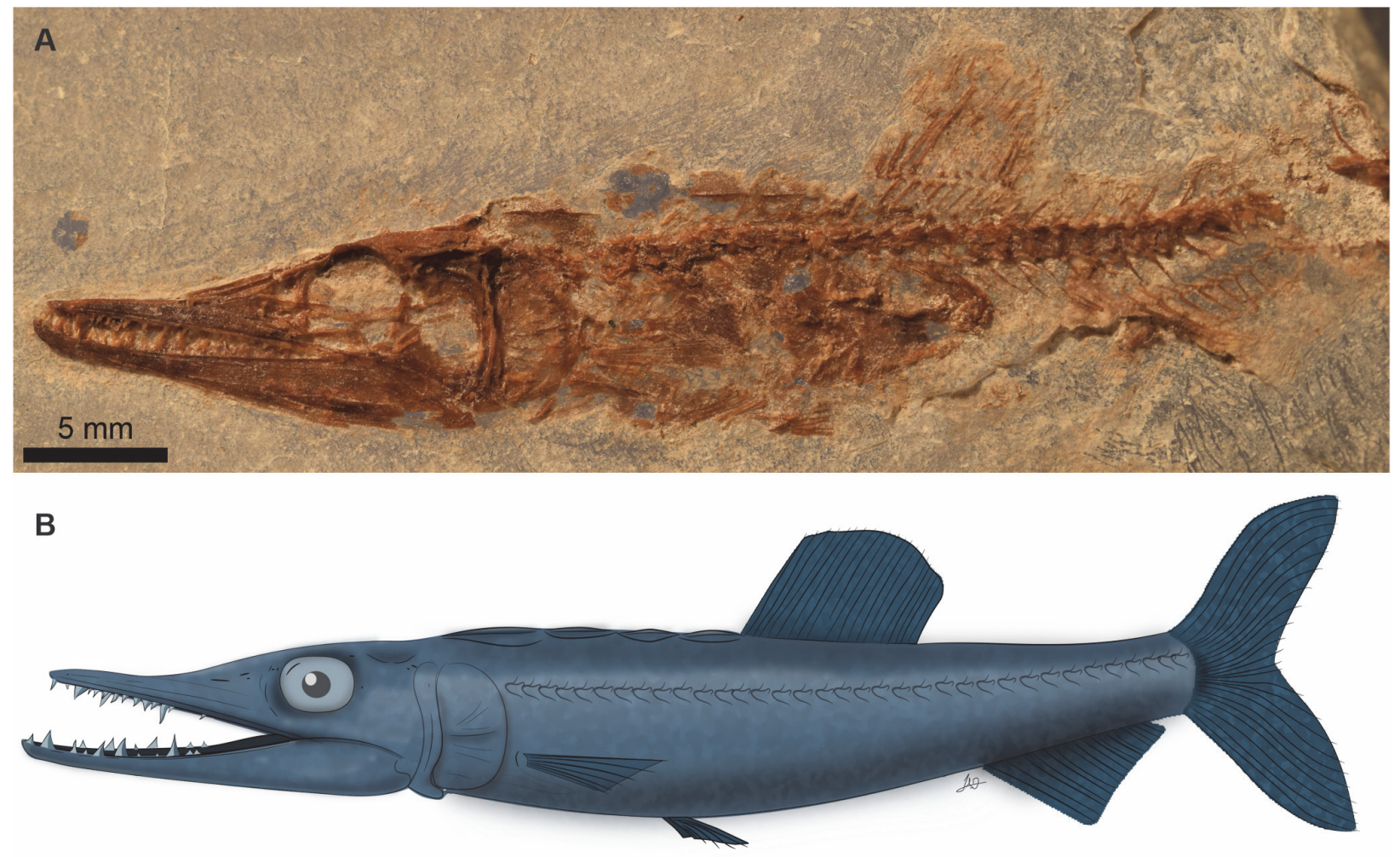

FIGURE 3. A) Lateral view of Vegrandichthys coitecus gen. et sp. nov., IHNFG 5927 holotype transferred in plastic resin from Early Cenomanian deposits of the El Chango quarry, Chiapas, Mexico. B) Artistic reconstruction of Vegrandichthys coitecus gen. et sp. nov. 

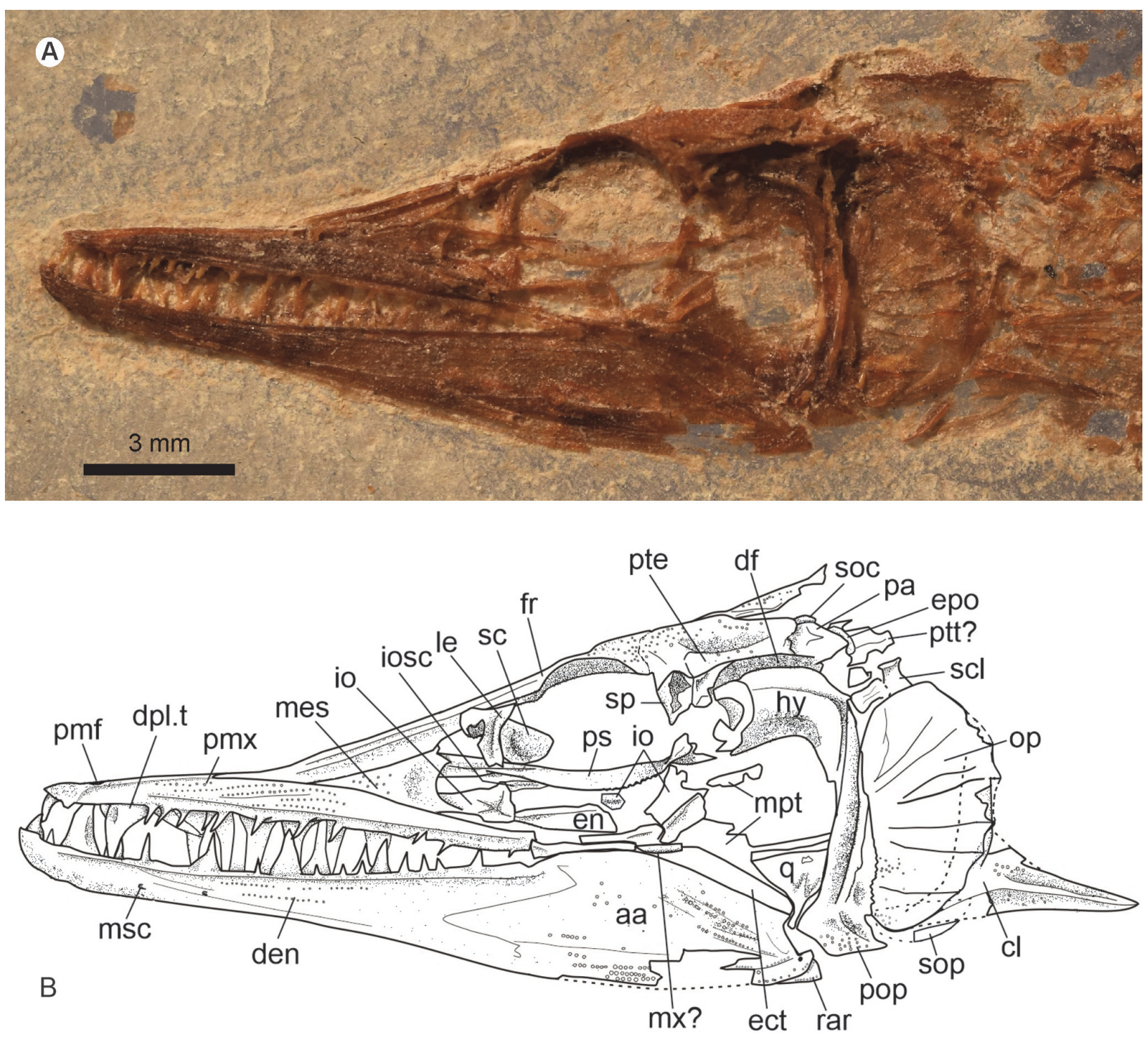

FIGURE 4. Vegrandichthys coitecus gen. et sp. nov. A) A close-up of the lateral view of the head; B) Drawing of the head and pectoral girdle in lateral view. Abbreviations: aa, anguloarticular; cl, cleithrum; den, dentary; df, dilatator fossa; dpl, dermopalatine, dpl.t, dermopaltine teeth; ect, ectopterygoid; en, endopterygoid; epo, epiotic; fr, frontals; hy, hyomandibula; io, infraorbital; iosc, infraorbital sensory canal; la, lacrimal; le, lateral ethmoid; mpt, metapterygoid; msc, mandibular sensory canal; mx, maxilla; op, opercle; pa, parietals; pmf, premaxillar fenestra; pmx, premaxilla; pop, preopercle; ps, parasphenoid; pte, pterotic; ptt, posttemporal; q, quadrate; rar, retroarticular; sc, sclerotic; scl, supracleithrum; soc, supraoccipital; sop, subopercle; sp, sphenotic.

skull length; the remaining $60 \%$ corresponds to the snout or preorbital region.

The body of IHNFG 5927 is shallow and fusiform. The head height $(\mathrm{HH})$ is relatively shallow, representing a little less than $40 \%$ of the head length $(\mathrm{HL})$ and is slightly less than the maximum body height that is present in the predorsal region of the trunk. The dorsal fin is short and placed in the posterior half of the abdominal cavity; the dorsal fin length and the predorsal length represent
$25 \%$ and $150 \%$ of $\mathrm{HL}$, respectively. The posterior end of the anal fin is unknown; however, it is longer than the dorsal fin and is located behind it. The anal fin base is at least $5.5 \mathrm{~mm}(28 \%$ of $\mathrm{HL})$ and rises at $203 \%$ of HL. The pectoral fin is in the lateral surface of the trunk, a little closer to the abdominal edge than to the vertebral column. The small pelvic fin is in ventral position and located in the predorsal region of the trunk, at $136 \%$ of the $\mathrm{HL}$. Behind the dorsal fin, the trunk progressively 

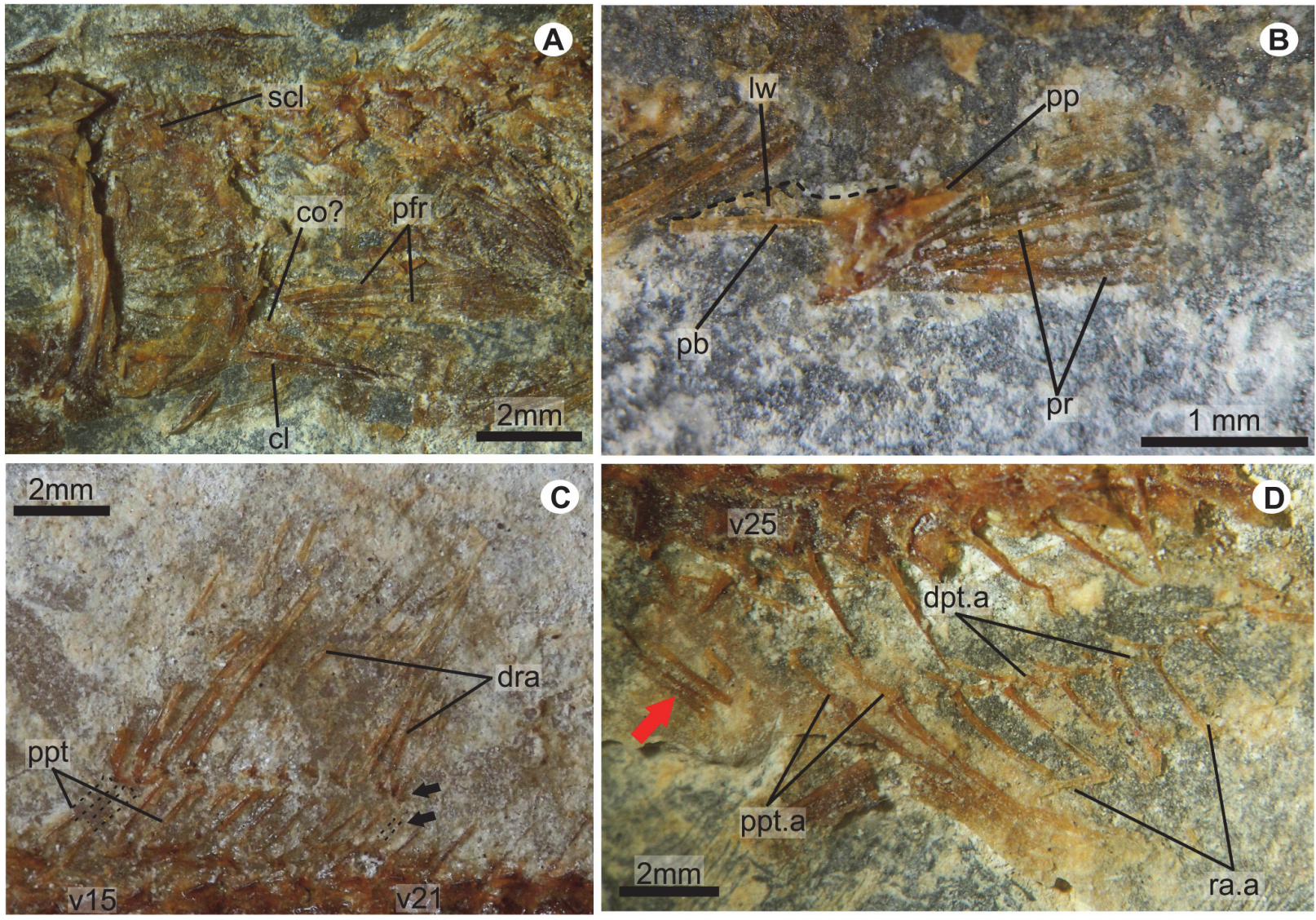

FIGURE 5. Close-up of different anatomical structures in the holotype of Vegrandichthys coitecus gen. et sp. nov. A) Pectoral girdle and fin, B) Pelvic girdle and fin, C) Dorsal fin and D) Anal fin. All anterior structures are laterally exposed. Abbreviations: cl, cleithrum; co, coracoid; dpt.a, anal fin distal pterygiophores; dra, dorsal fin rays; Iw, lateral wing; pb, pelvic bone; pfr, pectoral fin rays; pp, posterior process; ppt.a, anal fin proximal pterygiophores; ppt, proximal pterygiophores; pr, pelvic rays; ra.a, anal fin rays; scl, supracleithrum; v, vertebra.

tapers and probably behind the anal fin forms a shallow caudal peduncle.

Skull. The skull is triangular, anteriorly tapered, and about three times longer than high (Figure 4). Although the contact of the mesethmoid with the anterior tips of the frontals is covered by the anterior dorsal ends of the premaxilla, the frontals are likely at least three-quarters the length of the skull roof. The left frontal is dorsally exposed showing its flat and triangular shape, anteriorly pointed, slightly wider behind the orbit, and rectangular in the postorbital region. Behind the orbit, each frontal is firmly sutured with four bones; laterally with the sphenotic and pterotic and posteriorly with the supraoccipital and parietal. The supraorbital sensory canal runs along the frontal, near its lateral edge, enclosed above the orbit and exposed in its preorbital region. The frontals are superficially smooth along the preorbital region; in contrast, behind the orbit the frontals and other bones are strongly ornamented with small tubercles. The pari- etals are short triangular bones at the back of the skull roof, expanded laterally, and medially separated by a small supraoccipital bone.

The sphenotic is a small and triangular bone bordering the dorsoposterior orbital region; the pterotic is an elongated rectangular bone that reaches the back of the skull (Figure 4). The posttemporal fossa is a small depression in the region where the frontal, pterotic, and sphenotic converge. The dilator fossa is a shallow elongated depression laterally extended along the posterior two thirds of the pterotic and roofed by the sphenotic. The parasphenoid is an elongated laminar and straight bar extended along the orbital and the ethmoid region of the skull, with a flat and smooth lateral surface bearing numerous micro-serrations along the ventral edge of its posterior half.

None of the bones of the posterior region of the skull are exposed except for the epiotic, which seems to be short and wide. Much of the lateral otic region of the skull is covered by the hyoman- 

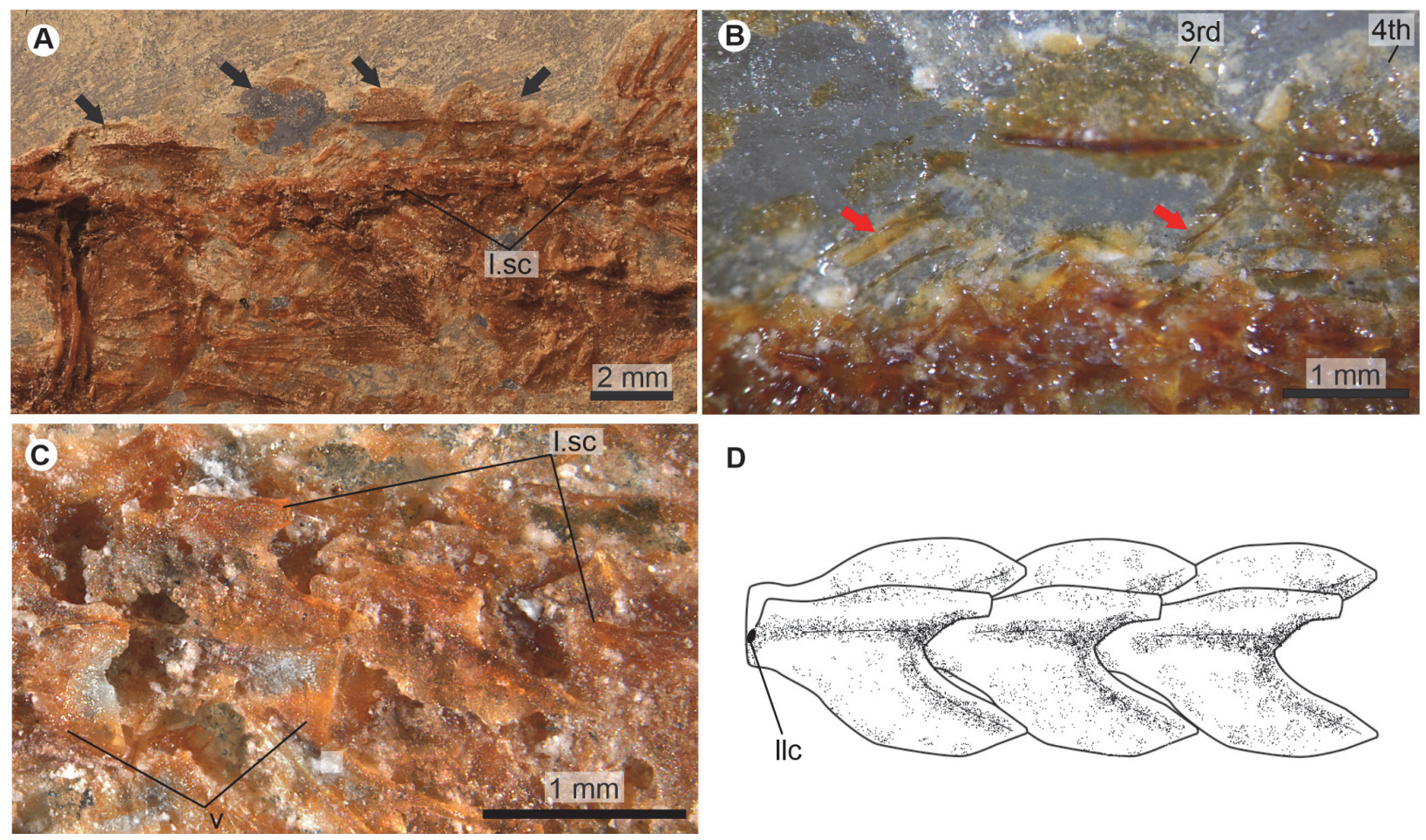

D

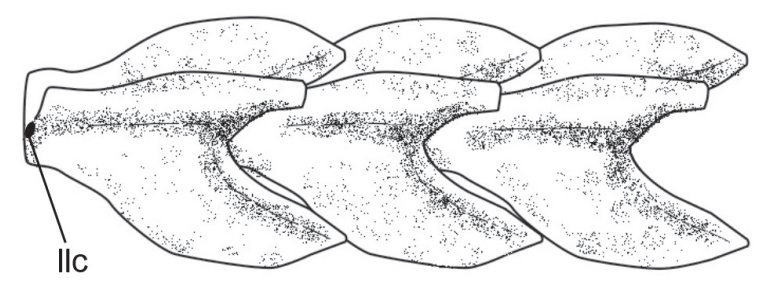

FIGURE 6. Scutes, scales and associated bones of Vegrandichthys coitecus gen. et sp. nov. A) Dorsal scutes series, B) close-up of the dorsal scutes region, C) close-up of the lateral line of scales, and D) drawing of the probable position and overlapping of the lateral line of scales. Abbreviations. Ilc, lateral lines canal; I.sc, lateral line scales; v, vertebrae. Ordinal numbers denote the number of dorsal scute. Black arrows point out each of the dorsal scutes. Red arrows point out the supraneurals.

TABLE 1. Measurements and body proportions of IHNFG-5927, holotype and single specimen of Vegrandichthys coitecus gen. et sp. nov. (all measurements are expressed in millimeters; + shows incomplete measurements and counts).

\begin{tabular}{lcc}
\hline \multicolumn{1}{c}{ Measurements and counts } & \% of HL \\
\hline Standard length (SL) & $52+$ & $?$ \\
Head length (HL) & 19.6 & 100 \\
Snout length (SL) & 9.8 & 50 \\
Head height (HH) & 7.5 & 38.2 \\
Maximum body height (MBH) & 7.8 & 39.7 \\
Predorsal length (PDL) & 29.7 & 151.1 \\
Preanal length (PAL) & 39.7 & 202.5 \\
Prepelvic length (PPL) & 26.7 & 136.2 \\
Dorsal fin length (DFL) & 4.9 & 25 \\
Anal fin length (AFL) & $5.5+$ & $?$ \\
Pectoral fin rays & 6 & \\
Dorsal fin rays/pterygiophores & $12 / 11$ & \\
Anal fin rays/pterygiophores & $13+/ 13+$ & \\
Pelvic fin rays & 5 & \\
Vertebrae (total/abdominal/caudal) & $30+/ 21 / 9+$ & \\
\hline
\end{tabular}


dibula. In the preorbital region, the lateral ethmoid is a thick triangular and somewhat curved bone that separates the nasal capsule from the orbit, it sutures with the ventral inner surface of the frontal, and ventrally projects below the parasphenoid. The anterior edge of the nasal capsule is covered by the lateral process of the mesethmoid bone, which is an expanded triangular and flat structure that meets the lateral anterior end of the frontal and is covered by the dorsal edge of the premaxilla (Figure 4).

Circumorbital series. The circumorbital bones are poorly preserved (Figure 4). This is an open series, with no dorsal bones. Remains of flat, rectangular, and flimsy infraorbital bones from the left and right sides of the head are preserved below the nasal capsule and the middle orbit. All these bones show the infraorbital sensory canal running near to their respective orbital edges, as well as few ventral branches of this canal. A large semicircular and flat basal sclerotic bone occupies the orbit.

Suspensorium. Bones of the suspensorium or hyomandibular series are only partially exposed (Figure 4). The hyomandibula is a large T-shaped bone in which the descending process is curved forward and the head is broad with a sinuous articular surface. The central region of this bone is reinforced with apicobasal ridges.

The quadrate is a laminar triangular bone with a small stout ventral head that is inclined forward. The symplectic and the joint between the ventral tip of the hyomandibular and the quadrate are obscured. The ectopterygoid is a laminar and toothless bone that is only partially exposed; its anterior region lies below the lower jaw while its spatula-like posterior part is tilted backward to meet with the quadrate anterior edge. The metapterygoid is laminar and poorly preserved, contacting the concave anterior margin of the hyomandibula and the dorsal edge of the quadrate. Only fragmentary, laminar, and toothless remains of the endopterygoid are preserved.

Although the dermopalatine is entirely covered by the premaxilla, a large, robust dermopalatine tooth is visible. This tooth seems to be placed at the anterior end of the bone, has a stout base, and a conical crown slightly curved backward and projected downward. The dermopalatine appears to bear multiple teeth, but the smaller posterior teeth are difficult to distinguish with precision.

Upper jaw. The upper jaw consists of two bones, the premaxilla and maxilla (Figure 4). There is no indication of a supramaxilla. The premaxilla is a flat triangular bone, pointed posteriorly, and extends for three quarters of the jaw. This bone has a single row of small, conical, sharp teeth, which are of similar size and evenly separated, except for a series of progressively smaller teeth along the posterior quarter of the bone. The anteriormost maxillary tooth is peculiar because it is slightly larger and rather sigmoidal. The dorsal ends of both maxillae are bent inwards to form the roof of the anterior half of the snout. A small midline fenestra, near the tip of the snout, presumably accommodated two teeth from the lower jaws. The outer surface of the premaxilla is intensely ornamented with small tubercles. Fragments of the maxilla reveal that this toothless, smooth, and rod-like bone is extended below the orbit.

Lower jaw. Three bones of the lower jaw are exposed in IHNFG 5927: dentary, anguloarticular, and retroarticular (Figure 4). In lateral view, the lower jaw is elongate, extending below the orbit and the anterior half of the otic region of skull. The first two fifths of its length are shallow, and it becomes progressively deeper more posteriorly: its deepest point is four times the depth of its shallowest point. Both the alveolar and ventral border are somewhat sinuous, the symphysis is very shallow, and the coronoid process is hardly recognizable. At the base of its posterior edge, the jaw has a small posteriorly-directed postarticular process. The mandibular sensory canal runs close to the ventral edge of the lower jaw. It is enclosed by bone, and opens through six pores scattered along the dentary and the anguloarticular bones. The entire labial surface of this jaw is ornamented with numerous tubercles.

The dentary is a triangular bone, occupies a large part of the lower jaw, and has a posterior deep and acute concavity to suture tightly with the anguloarticular bone (Figure 4). The alveolar border of the dentary occupies about two thirds of the jaw and bears two rows of teeth. The labial tooth row includes conical teeth in two sets: groups of one to three small and gracile conical teeth intercalated with larger isolated teeth with thicker bases. The lingual dentary tooth row consists of at least four sharp laterally compressed teeth exposed in the middle of the alveolar border, which resemble the longer teeth on the labial teeth row but they are thinner. Of the labial dentary teeth, the second isolated tooth is so developed that, in life, its tip must have penetrated the premaxilla through its dental fenestra. Since the specimen has single premaxillary dental fenestra, it is possible that the anterior ends of both dentaries were either very close or met in a long symphysial contact. 
Although the ventral anterior end of the dentary does not have osseous beards or dentary prongs (cf those of other enchodontids: Enchodus, Goody, 1969, figs. 36, 39; Unicachichthys, DíazCruz et al., 2016, figs. 5, 6; Veridagon, Díaz-Cruz et al., 2019b, fig. 3), it does display a series of conspicuous bony lumps. At this point, it is not possible to decide whether these osseous lumps are a preservation artifact, an analogy, or a homology of the dentary prongs of other specimens. In the absence of additional fossils, the authors consider that Vegrandichthys coitecus gen. et sp. nov. lacks dentary prongs.

The anguloarticular occupies the posterior $40 \%$ of the lower jaw (Figure 4). This triangular bone bears the postarticular process in which the small and shallow articular facet for the quadrate is exposed in lateral or labio-lingual view. A tiny wedge-shaped retroarticular covers the posteroventral corner of the postarticular process.

Opercular series. This series consists of three laminar bones, opercle, subopercle, and preopercle; the infraopercle is absent (Figure 4). The opercle is semicircular, about twice higher than long, and anteriorly straight and thick. An articular facet for the hyomandibular is borne near its anterior edge about a third of the way down. Seven thickened bars are present on the opercle, laterally exposed as longitudinal straight ridges; the central ridge is the most conspicuous. As the posterior edge of the opercle is very thin, it is not clear whether the bars form true spines or not. The lower third of the opercle is superficially ornamented with tubercles.

The preopercle is a triangular bone, about 2.5 times higher than long, dorsally pointed, ventrally convex, and expanded anteriorly and posteriorly (= "widens anterior and posteriorly" in Fielitz, 2004) (Figure 4). The anterior edge is thickened, slightly convex, and its base is expanded anteriorly; in contrast, the posterior edge of the preopercle is rather laminar, convex, bears small serrations, and its base forms a posterior thick and conspicuous spine. The preopercle is smooth except for small tubercles borne on its ventroposterior limb. The preopercular sensory canal is enclosed by bone and opens externally through two or three pores present in the ventroanterior preopercle limb.

Although the subopercle is poorly preserved and largely covered by the opercle, some remains of this laminar bone are preserved behind the preopercle and below the opercle. Apparently, the subopercle is ornamented with small tubercles (Figure 4).
Branchiostegal rays and gill arches. No element of the branchiostegal rays or the gill arches are exposed.

Vertebral column. Unfortunately, the specimen does not preserve the posterior part of the body; however, a large part of the vertebral column is exposed and consists of at least 30 total vertebrae, including 21 abdominal and at least nine caudal (Figures 3A, 5, 6A). All centra are hourglassshaped bones and slightly constrained in the center. The centra in the middle of the body are about two times longer than high, while those placed in front and back are slightly and progressively shorter, and become about 1.5 times longer than high. Laterally, a couple of thick longitudinal ridges reinforce the centra. Along the vertebral column, the centra have no parapophyses or zygapophyses, and each centrum is fused with its respective dorsal and haemal arches and spines. The haemal and neural spines are uniformly thick, straight and inclined backward. In the abdominal centra, ribs are present as bars with a small articular head and a sharp distal tip.

At least two supraneurals are present below the predorsal scutes and between the occiput and the dorsal fin rays (Figure 6B). These spatula-like bones have a differentiated dorsal head that is anteriorly and posteriorly expanded, as well as an anteriorly directed elongated and straight ventral limb. Along the abdominal centra there are threadlike epineurals inclined backward that probably extended along three or four centra from the lateral surfaces of the neural arches. Remains of posteriorly directed thread-like epipleurals are present along the abdominal region.

Pectoral girdle and fin. Pectoral girdle bones are relatively poorly preserved or obscured (Figures 4, $5 A)$. Only fragments of the left posttemporal bone are present behind the skull of the specimen. Most of the supracleithrum is covered by the opercle; only its dorsal end is exposed. The cleithrum is an inverted T-shaped bone in which the dorsal and anterior limbs are not completely observed. The posterior limb of the cleithrum forms a large spiny ventral process that projects posteriorly, and its longitudinal axis is reinforced by a conspicuous ridge. The cleithrum seems to be a smooth bone except for the posterior spine that is ornamented with small tubercles. No postcleitra are preserved.

The left pectoral fin is located above the ventral posterior spine of the cleithrum (Figure 5A). This fin consists of six distally branched and segmented rays. Only fragments of the coracoid are 
preserved. The length of the pectoral fin equals four and a half abdominal vertebrae (Figure 3).

Pelvic girdle and fin. The pelvic fin is set on the anterior half of the abdomen on its ventral border and rises below the abdominal centrum 10. The length of the pelvic fin hardly equals that of two abdominal centra. This fin consists of five distally segmented and branched rays, which are supported on the posterior edge of the pelvic bone. This triangular bone has a laminated triangular lateral wing and a stout and short posterior process (Figure 5B).

Dorsal fin. The dorsal fin is contained within the posterior half of the abdominal cavity (Figure 3). It consists of 12 distally branched and segmented rays supported by 11 stick-like proximal pterygiophores (Figure 5C). This fin is rounded because the length of those rays in the middle of the fin equals the length of the base while those placed on the front and back are progressively shorter. The base of this fin is extended above the last six abdominal centrae (15-21). The dorsal fin rays are located close to the body because of the lack of distal pterygiophores.

Anal fin. The anal fin originates posteriorly to the dorsal fin (Figure 3 ). The posterior edge is not preserved, but there are 13 longitudinally grooved and distally segmented rays supported by 13 rod-like and straight proximal pterygiophores (Figure 5D). In the posterior two thirds of the anal fin, there are noticeably elongated distal pterygiophores causing the separation of the associated anal rays. Although the anterior anal fin rays are fragmented; it seems that the fin was roughly triangular in shape. The anal fin extends below the vertebrae 25 to 31 ; however, its first three proximal pterygiophores are projected into the space between the haemal spines of the first caudal centra (22 and 23).

Caudal skeleton and fin. The caudal fin is not preserved.

Squamation. The body is almost entirely naked (Figures 3A, 6A-D). However, the predorsal trunk edge bears a row of four predorsal scutes. The lateral line is enclosed by a single row of modified scales exposed along each body flank.

The predorsal scutes are ovoid structures, about two times longer than wide, forming a continuous row where the posterior end of one scute is in contact with the anterior tip of the subsequent scute (Figures 4, 6A-B). These scutes consist of a median longitudinal keel with a pointed posterior margin. Either side of the keel, a semi-ovoid lateral wing expands laterally to cover the predorsal edges of both body flanks. The entire outer surfaces of these scutes are intensely ornamented with numerous tubercles.

The modified flank scales of the lateral line are thin sinuous structures with rounded edges. A prominent keel is present on the midline, and either side of this is a posteriorly projecting subrectangular lobe (Figures 3, 6C-D). In the abdominal region these scales are rectangular, slightly higher than long, around two thirds the length of each vertebral centrum, and are placed slightly above the vertebral column. In contrast, the scales close to the caudal region are progressively smaller, shallower, and located at the level of the centra. The longitudinal axis of these scales encloses a tube that housed the lateral sensory canal. Additionally, above the canal, each scale has a conspicuous, laminar, and triangular keel that projects posteriorly.

\section{Taxonomical Remarks}

The family Enchodontidae has been studied by many authors (Fielitz, 2004; Silva, 2007; Fielitz and González-Rodríguez, 2010; Silva and Gallo, 2011; Cavin et al., 2012; Díaz-Cruz et al. 2016, 2019a), who agree on its monophyly but disagree over the inclusion of Rharbichthys and the composition of its subfamilies. Vegrandichthys coitecus gen. et sp. nov. exhibits some of the characters already included in the diagnosis of this family, such as the lack of interopercle and supraorbital, the presence of the horizontal strengthening bar on the opercle, tubercles ornamenting the opercle and subopercle, and a series of predorsal scutes between the occiput and the dorsal fin (Figures 3$6)$. Therefore, the inclusion of Vegrandichthys into the family Enchodontidae is strongly supported.

Additionally, Vegrandichthys coitecus gen. et sp. nov. possesses a peculiar combination of characters that is unique among enchodontid genera. Most enchodontids have preopercles with no posterior spines; however, Vegrandichthys and Unicachichthys share the presence of a posterior spine at the base of the preopercle. Such spine is short in Vegrandichthys (Figure 5) compared to that of Unicachichthys (Díaz-Cruz et al., 2016, fig.5).

Among enchodontids, as previously known, there are five different body patterns defined based on the different shapes of the snout and trunk: 1) a short snout and rather pisciform trunk as in Enchodus, Unicachichthys, and Veridagon [see Figure 1] ; 2) a short snout and rather rounded, short and high trunk, as in Parenchodus; 3) a short snout and 
very long trunk as in Palaeolycus; 4) a moderately long snout and perciform trunk as in Eurypholis; 5) a long snout and very long trunk as in Saurorhamphus. The body pattern displayed by Vegrandichthys gen. nov. resembles that of Eurypholis; however, the length of the snout is intermediate between those seen in Eurypholis and Saurorhamphus.

Additionally, among enchodontids the articulation between the lower jaw and the quadrate shows two conditions. This articulation is laterally covered by a posterior extension of the anguloarticular bone in Eurypholis and Saurorhamphus, but laterally exposed in other enchodontids. Vegrandichthys gen. nov. shares the second condition with Enchodus, Parenchodus, Unicachichthys, Veridagon, and Palaeolycus.

Finally, among enchodontids, the opercle also shows two conditions. The posterior border of this bone is rounded and continuous in Enchodus, Parenchodus, Unicachichthys, Veridagon, and Palaeolycus. In contrast, in Eurypholis and Saurorhamphus the longitudinal crest in the middle of this bone is extended, forming a posterior spine. Again, in this case Vegrandichthys gen. nov. shows the first of the conditions; however, this new fish is unique because it has additional strengthening longitudinal crests in the preopercle.

\section{Phylogenetic Results}

The Standard Maximum Parsimony (SMP) analysis retained one most parsimonious tree of total length 316 steps $(\mathrm{Cl}=0.456$ and $\mathrm{RI}=0.693)$ (Figure 7). The SMP analysis resolves Enchodontidae as a monophyletic family comprising the genera Enchodus, Eurypholis, Palaeolycus, Parenchodus, Saurorhamphus, Unicachichthys, Veridagon, and the monospecific genus herein described, Vegrandichthys.

In this phylogenetic exercise, Vegrandichthys coitecus gen. et sp. nov. is supported as an enchodontid by the presence of four synapomorphies (Figure 5; node a): i) anteroventral prongs present; ii) supraorbital bone absent; iii) pelvic fin at or posterior to the dorsal fin; iv) opercular and subopercular dermal pattern as ridges with tubercles along each ridge. Vegrandichthys is placed in Eurypholinae as the sister taxon of the clade composed by Eurypholis + Saurorhamphus, on the basis of a single character: ventral portion of the cleithrum anterior and posteriorly widened (Figure 7; node d). Overall, in our phylogenetic analysis, the Bremer and bootstrap values across the retained tree are low.
The placement of Vegrandichthys coitecus gen. et sp. nov. as a member of Eurypholinae was also consistent in all the additional phylogenetic analyses carried out. The analysis based on Phylogenetic Morphometrics (PM) of the preopercle landmark configuration retained only one tree with best score $=0.04079$. This phylogenetic hypothesis suggests, in addition, a close relationship between Unicachichthys and Eurypholinae (Figure $8 \mathrm{~A}-\mathrm{B})$.

The phylogenetic analysis with Implied Weighted Maximum Parsimony (IWMP) recovered the same topology regardless of parameters $(k=10$ and $k=100$; Figure $8 \mathrm{C}$ ). However, the best score was different for each analysis ( $k=100: 1.6622$; $k=10 ; 12.9163)$. These results show the same phylogenetic relationships displayed in the analysis of SMP for all the taxa.

The phylogenetic hypothesis obtained with Bayesian Inference (BI) shows a very different topology with respect to those obtained with other methods (Figure 8D). Nevertheless, Eurypholinae keeps the same composition, and Vegrandichthys retains its phylogenetic placement in the subfamily.

The analysis combining morphological discrete data with the landmark configuration of the preopercle retained only one tree with tree length $=316.04924$, of which 0.04924 is the preopercle configuration contribution (Figure $8 \mathrm{E}$ ). The phylogenetic position of the new taxon and the composition of Eurypholinae agree with the topology recovered with SMP, IWMP and BI.

In all the performed analyses the support values of the clades in the subfamily Eurypholinae, as well as their posterior probabilities, are among the highest values across the tree.

On the other hand, the stratigraphic fit analysis showed that the inclusion of Enchodus zimapanensis decreased the level of stratigraphic fit of Enchodontidae: stratigraphic fit is far more consistent in the analyses that excludes E. zimapanensis (Figure 9). Randomly generated ages in the first analysis improved slightly the stratigraphic fit, but in the second analysis they decreased it.

\section{DISCUSSION}

The monophyly of Enchodontidae has been repeatedly corroborated, as shown by Fielitz (2004), Silva and Gallo (2011), Díaz-Cruz et al. (2016, 2019b), and Vernygora et al. (2017); this finding is also supported in the present work. However, characters supporting the monophyly of the family differ from those reported in previous works. Originally, Fielitz (2004) found that the presence of 


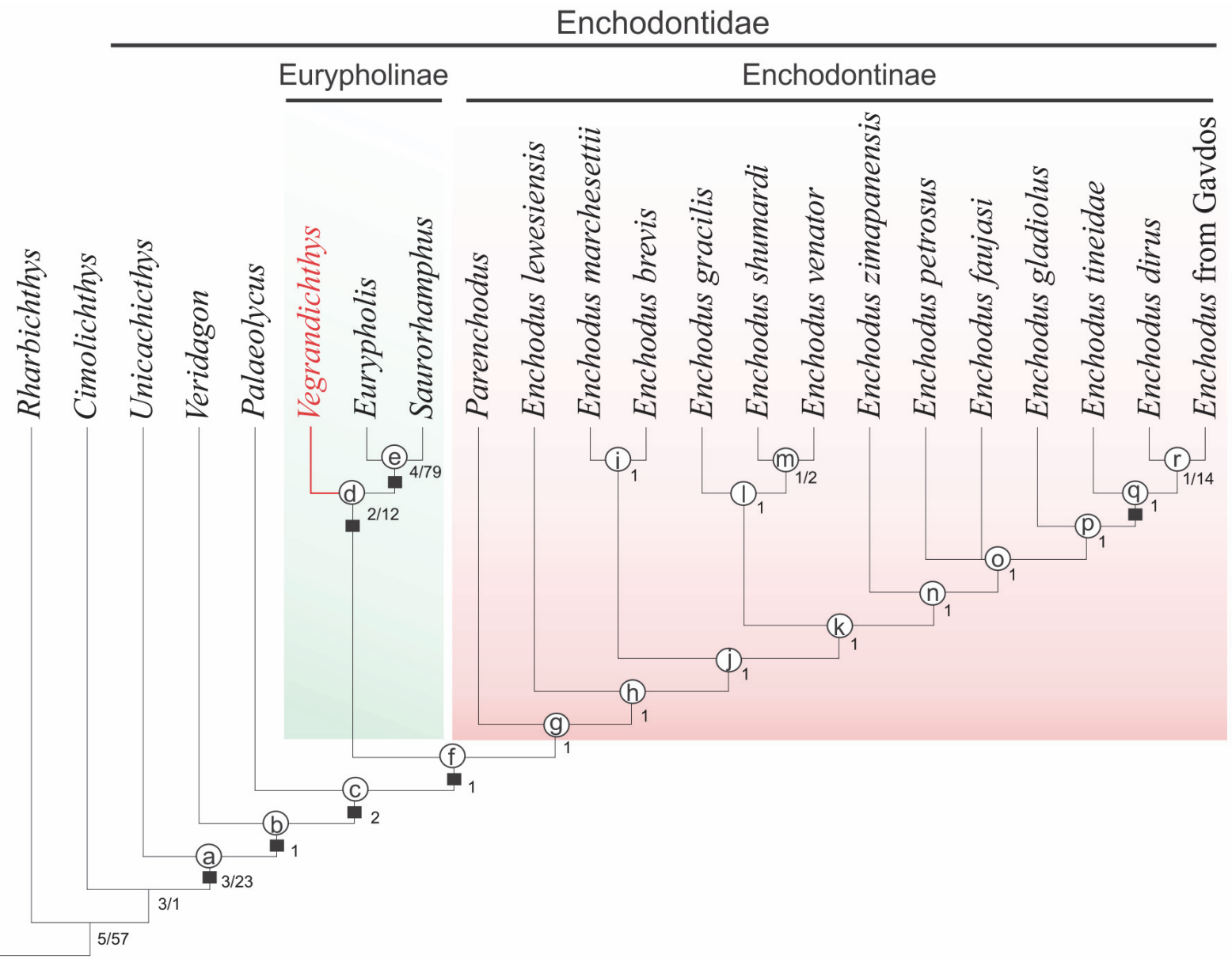

FIGURE 7. Phylogenetic relationships of Enchodontidae including Vegrandichthys coitecus gen. et sp. nov. obtained following the protocol described of the Standard of Maximum Parsimony $(T L=316, \mathrm{Cl}=0.456, \mathrm{RI}=0.693)$. The subfamily Eurypholinae in green background and Enchodontinae in red background. Numbers by nodes indicate the supports values of Bremer/Bootstrap. Black squares indicate the presence of synapomorphic characters in Enchodontidae. Node a, Enchodontidae: presence of anteroventral prongs (36:1); absence of supraorbital bone (43:1); pelvic fin at or posterior to the dorsal fin in position (52:1); opercular and subopercular dermal pattern as tubercles (55:2). Node b: Laminar posterior limb in the ventral portion of the preopercle (50:0). Node c: Ectopterygoid teeth between six to eight teeth with the second tooth longest (12:2). Node d, Subfamily Eurypholinae: Ventral portion of cleithrum widens anteriorly and posteriorly (60:2). Node e: Laterally exposed articulation mandible-quadrate (34:1); Opercular horizontal strengthening ridge continues past posterior edge to form a spine (52:2). Node f: Mandibular dermal pattern as ridges with tubercles along each ridge (41:2); Preopercular dermal pattern as ridges with tubercles (54:2). Node q: Sigmoidal lateral view of dermopalatine teeth (16:2). Numbers by nodes show the Bremer/Bootstrap values. The subfamily Enchodontinae is only supported by homoplastic characters, therefore, we omitted them in the node description. Full description and character mapping are in Appendix II.

a single dermopalatine tooth, the dermopalatine bone same length or shorter than the tooth and the absence of interopercle were the diagnostic characters for Enchodontidae. This was modified by Silva and Gallo (2011), who proposed that the only synapomorphy for Enchodontidae is the presence of middorsal scutes. Díaz-Cruz et al. (2016:146) and Vernygora et al. (2017:12) recovered the same character as the single unique synapomorphy for Enchodontidae. However, the phylogenetic analy- sis of Enchodontidae performed by Díaz-Cruz et al. (2019b:280) challenged this hypothesis. These authors found that, after adding Veridagon avendanoi to the phylogeny, characters supporting the monophyly of Enchodontidae were: presence of anteroventral prongs, absence of supraorbital bone, dermal pattern on opercular and subopercular as ridges with tubercles along each ridge, and the presence of a horizontal bar on the opercular. The phylogenetic exercise presented here, partially 

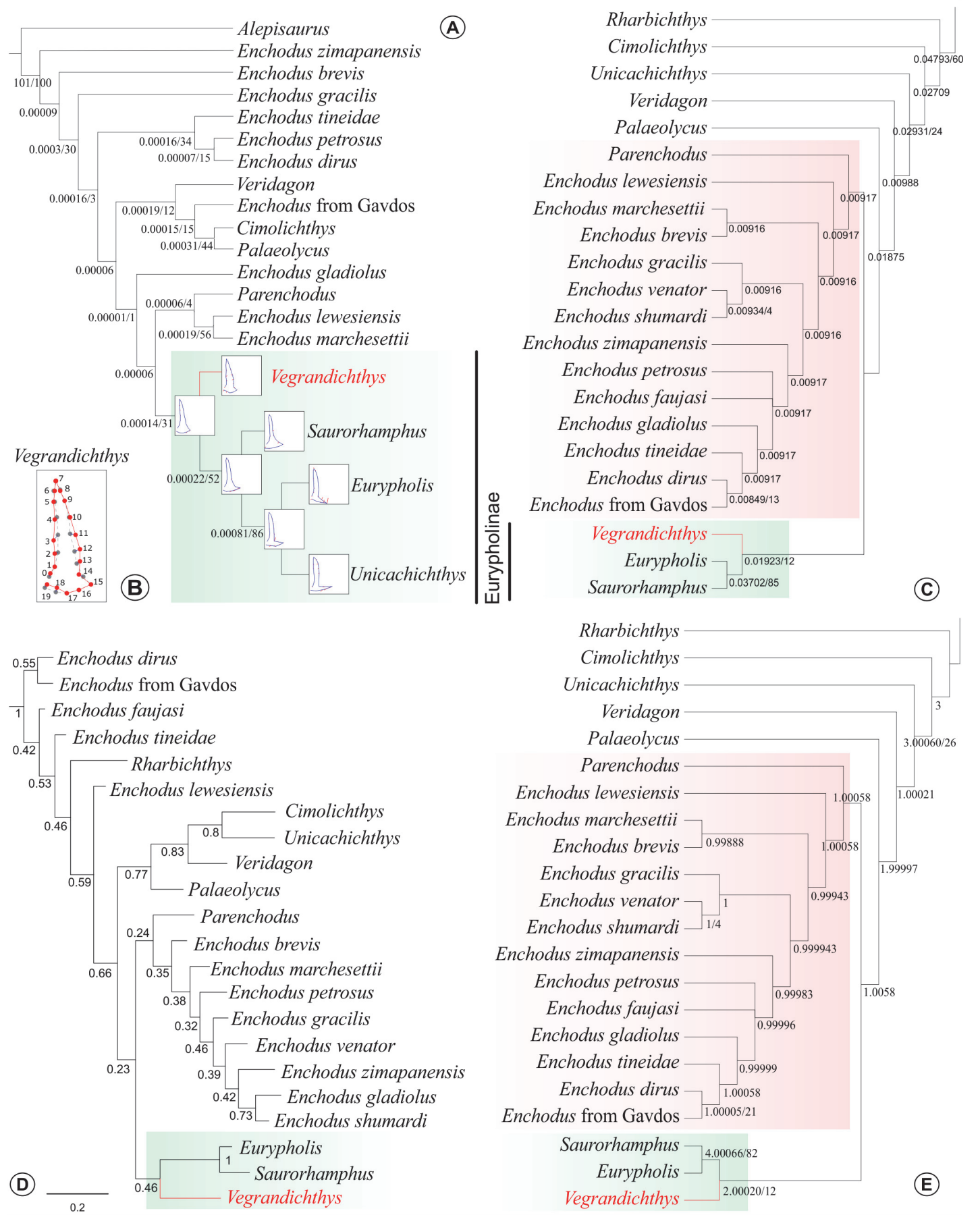

FIGURE 8. Results of the inclusion of Vegrandichthys coitecus gen. et sp. nov. in the phylogeny of Enchodontidae using multiple phylogenetic approaches. A) The one retained tree of Enchodontidae with the Phylogenetic Morphometrics (PM) method using only landmark data, the Best Score reached $=0.04079$. B) Dots in red correspond to the landmark configuration of the preopercle used to run the PMA. C) Implied Weighted Maximum Parsimony (IWMP) tree (the same tree topology with $\mathrm{K}=10$ and $\mathrm{K}=100$ ) based exclusively on discrete morphological data. $\mathrm{D}$ ) Maximum a Posteriori (MAP) phylogeny obtained with Bayesian Inference. E) Tree obtained with the combined matrix of morphological discrete data and the landmark configuration of the preopercle, using Standard Maximum Parsimony; Best score = 316.04924. In green background is the subfamily Eurypholinae, except in A that includes Unicachichthys. Background in red is the clade formed by Parenchodus + Enchodus species. In all the phylogenetic analyses Vegrandichthys coitecus gen. et sp. nov. new is recovered as a member of the subfamily Eurypholinae along with Eurypholis and Saurorhamphus. Numbers by nodes indicate Bremmer / bootstrap (when present) values except in D, where numbers indicate the posterior probability. Full phylogenetic hypotheses and their description can be accessed in Appendix II. 


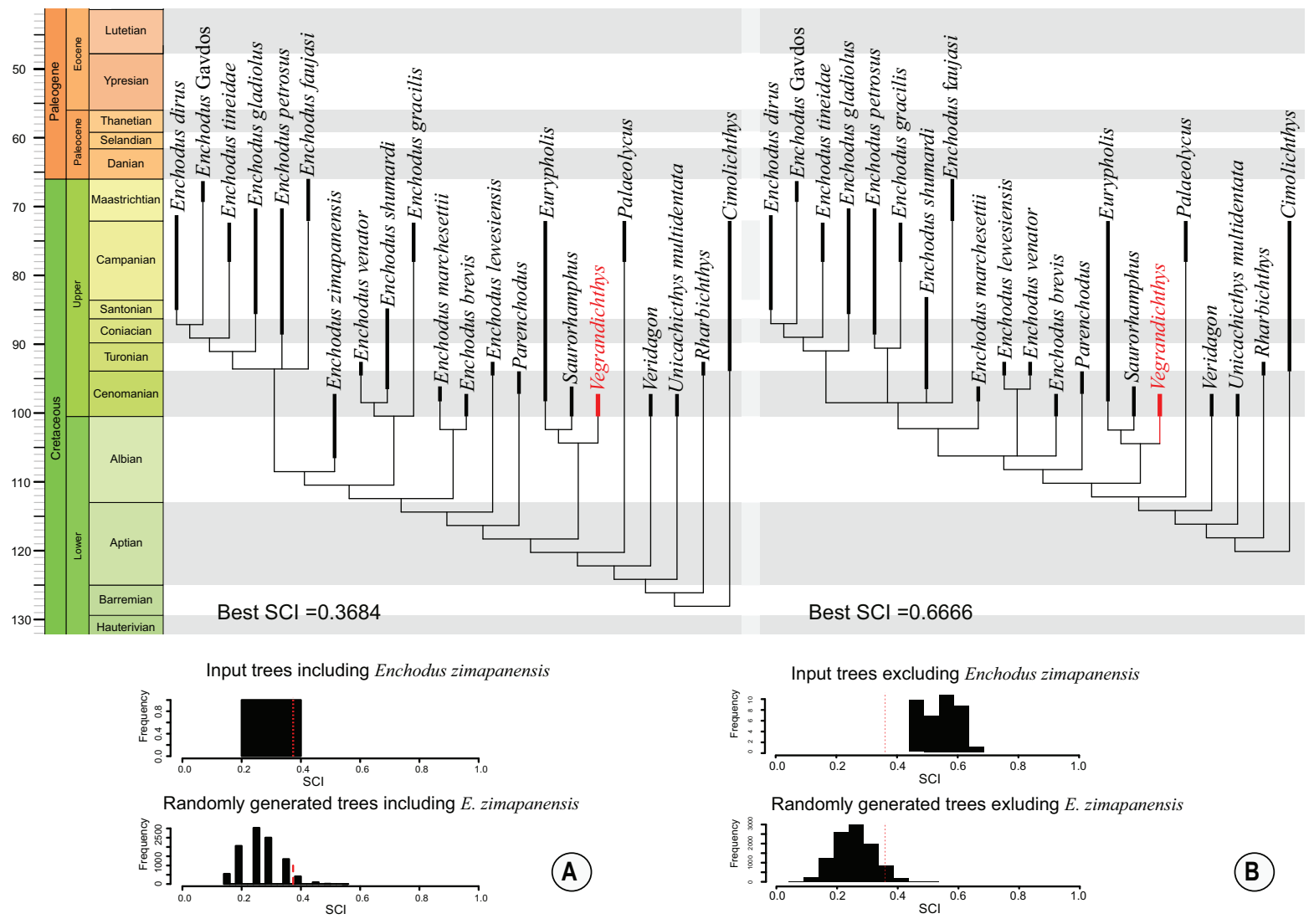

FIGURE 9. Assessment of the stratigraphic congruence in Enchodontidae. A) Phylogeny including Enchodus zimapanensis and B) phylogeny excluding it. Both phylogenies time-calibrated and plotted against the ICS 2019 data. Red branch points out the phylogenetic position of Vegrandichthys coitecus gen. et sp. nov. Below each tree, there are the histograms of the $\mathrm{SCl}$ for the input and randomly generated topologies.

agrees with the results described by Díaz-Cruz et al. (2019b), also recovering the first three characters, but additionally finding the pelvic fin at or posterior to the dorsal fin in position $(52: 1)$ as a synapomorphy. Moreover, in the work of Díaz-Cruz et al. (2019b) as well as the present work, Rharbichthys is excluded from Enchodontidae.

It is important to highlight that the phylogenetic analysis of Silva and Gallo (2011) is aimed at understanding phylogenetic relationships within the suborder Enchodontoidei, and included Dercetidae and other incertae sedis taxa [see Silva and Gallo (2011) and Vernygora et al. (2017)] in addition to Enchodontidae. Because of this different focus, the morphological characters and formulations of primary homology vary from those used in this manuscript. In contrast, the data matrix employed by Fielitz (2004) focuses on the relationships between enchodontids and extant forms, and therefore serves as a backbone for our study. The character pertaining to dorsal bony scutes (c.78 in Fielitz
2004; c.83 in the present work) also captures information relating to dermal ornament, which may not be independent (Simões et al., 2017). Furthermore, compound characters such as this are recognized to be problematic (Brazeau, 2011; Simões et al., 2017), and this may account for the presence of dorsal scutes not being recovered as a synapomorphy for the family.

Time calibrated phylogenies of Enchodontidae show that most taxa are restricted to the earliest period of the Late Cretaceous, suggesting a Cenomanian 'explosion' for the group. However, inclusion of Enchodus zimapanensis decreases the stratigraphic fit of the family, suggesting that the evolutionary history of Enchodontidae is far from complete. Recent work by Díaz-Cruz et al. (2019a) reporting additional Enchodus species from the Middle East supports this, but the full implications of these findings on enchodontid phylogeny are not yet known. Isolated teeth with enchodontid affinity have also been reported from 
lower Barremian strata of Alcaine, Spain (Kriwet, 2003), and specimens referred to Enchodus sp. are known from the early Aptian-late Barremian of Morro de Chaves formation, Alagoas, Brazil (Coelho, 2004; García et al., 2018). Unfortunately, due the incompleteness of these records, and their uncertain taxonomical affinity, it is not possible for us to include them in our analysis. In the meantime, the finding and formal description of Vegrandichthys, the first Eurypholinae from the Americas, strengthens the importance of this territory for better understanding Enchodontidae evolution.

\section{Multi-approach Study in Enchodontidae}

Although the main objective of this manuscript is not the assessment of the "best" phylogenetic method, the use of multiple criteria to reconstruct phylogenetic relationships with an empirical data set revealed some interesting results.

First, the topology of the single shortest tree recovered using Standard Maximum Parsimony criterium did not differ from those topologies obtained with Implied Weighted Maximum Parsimony. Goloboff et al. (2018) stated that implied weights, in general, outperforms equal weights parsimony even in the presence of missing entries. However, our results are consistent and there is no discrepancy among the groups found by each variant of parsimony.

Our Phylogenetic Morphometrics (PM) analysis of the landmark configuration of the opercle also appears to carry a reliable phylogenetic signal, despite not including information for all taxa in the analysis. Catalano et al. (2014) found that Phylogenetic Morphometrics only retrieve some clades found by other source of data, and that it is necessary to consider multiple landmark configurations in order to improve correspondence of results (Catalano and Torres, 2016). In this manuscript, we only assessed the landmark configuration of the preopercle, a bone that exhibits a high morphological variation. However, employing the searching algorithm in TNT that minimize the displacement of the landmark sum (Catalano et al., 2010) was effective to find true phylogenetic signal. Future work will include landmark configurations on other bones, including those with a variable shape (e.g. the preopercle) on which homologous points are difficult to identify.

Moreover, it is known that the combination of landmark with discrete data might produce data redundancy if the landmark configuration is also considered by discrete characters (Palci and Lee, 2018). The results of our combined analysis show that the inclusion of the landmark configuration in the discrete data set does not modify the topology retrieved by the SMP analysis (see Figure 5) even though, discrete characters of the preopercle shape remained in the data matrix. We ascribe these results to the very low contribution of the landmark data as well as to the increase in the length of discrete characters that avoided the examination of landmarks (Goloboff and Catalano, 2016:226) producing, in the combined data analysis, lower computing time and a topology markedly different from that analyzing exclusively landmark data.

Additionally, as a result of analyzing and discretizing the data related to the preopercle in our data set, we observed that special attention should be paid when dealing with landmark combined with discrete data for two main reasons. First, when analyzed as a whole, a landmark configuration tries to equal the weight of a discrete character (e.g shape of a given bone). However, there are some conditions that cannot be covered by a 2D landmark configuration, such as the thickness of the bone. Second, the shape of a bone can be distilled into several discrete characters, thus, the contribution sum of multiple discrete characters may be higher than that of the landmark configuration, unless extra weight is put to the landmark character. In our combined exercise, landmark information can be seen as a complementary source of information rather than a substitute of discrete characters as previously described by other authors (Perrard et al., 2015; Palci and Lee, 2018), but further analyses in this regard are required.

Finally, according to our results, Bayesian Inference analysis (BI) seems to be more sensitive to the quality of the data than parsimony analyses. The comparison of the tree topology obtained with Bayesian Inference with that of the Standard Maximum Parsimony (SMP) shows a great difference in the branch arrangement. However, many of the internal nodes in the parsimony analyses are poorly supported (Figure 5), with low support values and few synapomorphic characters. In general, this phylogeny shows that the $\mathrm{Cl}$ of the data set is 0.456 . Puttick et al. (2018) found that if the dataset contains consistent characters and its $\mathrm{Cl}$ is about 0.5 or higher, then the method used to infer relationships is irrelevant, with similar results recovered across different analyses. SMP resolves a high level of homoplasy in our dataset, which may account for topological differences between parsimony and Bayesian analyses. However, the phylogenetic position of Vegrandichthys gen. nov. and 
composition of Eurypholinae are consistent across our analyses, likely due to the relatively high support for this clade, and indicating a high level of support for the accuracy of this result (Goloboff et al., 2018). To more completely assess these first impressions in $\mathrm{Bl}$ with Enchodontidae, it will be necessary to conduct a thoughtful revision of character reformulations.

\section{CONCLUSIONS}

Vegrandichthys coitecus is recognized as a new member of the family Enchodontidae, as indicated by multiple phylogenetic approaches. Its phylogenetic position as an early-diverging member of the subfamily Eurypholinae is also well-supported. While our analyses recover enchodontid monophyly, the synapomorphies upholding this vary from some previous works.

Although the stratigraphic fit of Enchodontidae decreases when Enchodus zimapanensis is included in the analysis, there is no doubt about the importance of the inclusion of enchodontids with temporal record earlier to the Cenomanian, in terms of both the origin of the family and its palaeobiogeographical distribution. Future work focusing on stratigraphically older members of the group is vital to understand its origins.

Congruence of results across multiple phylogenetic analyses indicates the robustness of our results. Phylogenetic Morphometrics is an excellent tool for exploratory analyses of shape variation; it can be used as a first approach to study anatomical change of an entire bone under parsimony criteria. Fossil preservation bias and specimen incompleteness limits the use of this kind of tool, but even partially preserved elements can be incorporated to some extent. The contribution of a single landmark configuration may be too little to influence topology, and future work should consider multiple landmark configurations in combined analyses, while also taking into account potential data redundancy. In this sense, we recommend performing analyses separately as well as in a combined approach in order to examine the influence of different kinds of data.

Bayesian Inference appears to be more sensitive to data consistency, and future work should test the influence of states of character frequency.
A reformulation of anatomical characters, in particular to consider primary homologies and avoid compound characters, may also be necessary to fully understand the evolutionary history of Enchodontidae.

\section{ACKNOWLEDGMENTS}

This manuscript represents a partial fulfillment of the requirements to obtain the degree of Doctor in Biological Sciences (Systematics) within the Posgrado en Ciencias Biológicas at Universidad Nacional Autónoma de México for the first author. The authors thank all the paleontologists, students, and volunteers involved in the collection of fossils from the El Chango quarry, mainly to the staff of the Museum of Paleontology "Eliseo Palacios Aguilera" (MEPA) who is in charge of the "Poyecto de prospección y resguardo del patrimonio paleontológico de Chiapas" and the Instituto de Geología, Universidad Nacional Autónoma de Mexico. The preparation of the specimen was performed by B.A. Than-Marchese. Dr. M. Bertling, Dr. T. Smith, and Dr. A. Folie from Geomuseum der WWU and the Royal Belgian Institute of Natural Science provided valuable historical references of Enchodontidae. Authors are also deeply grateful with all the curators of the paleontological collections that kindly gave us access to review and borrow fossils material herein reviewed especially to MSc. G. Carbot-Chanona from the MEPA, Chiapas, Mexico; Dr. K. González-Rodríguez from the Museo de Paleontología, UAEH, Mexico; Dr. D. Arbulla from the Museo Civico di Storia Naturale di Trieste, Italy; Dr. E. Bernard and Dr. M. Richter from Natural History Museum, UK; Dr. M. Bertling from the Geomuseum der WWU, Münster, Germany. Likewise, to Dr. C. Fielitz for the comments and discussion on Enchodontidae held in the SVP Albuquerque 2018. This manuscript was improved with valuable suggestions provided by Dr. K. Cantalice and two anonymous reviewers. The development of this project is supported with Financial found provided by the UNAM through the grant from DGAPA-PAPIIT IN207314 and the individual postgraduate grant number 632640 given to JADC from CONACyT (Mexico) as well as support from the University of Birmingham and Royal Society Dorothy Hodgkin Research Fellowship to SG. 


\section{REFERENCES}

Agassiz, J.L.R. 1833. Recherches sur les poisons fossils, Volume 1 (preface dated in 1833). Neuchâtel et Soleure, Petitpierre.

Alvarado-Ortega, J., Cantalice, K.M., Barrientos-Lara, J.I., Díaz-Cruz, J.A., and Than-Marchese, B.A. 2019. The Huehuetla quarry, a Turonian deposit of marine vertebrates in the Sierra Norte of Puebla, Central Mexico. Palaeontologia Electronica, 22.1.13:1-20. https://doi.org/ $10.26879 / 921$

Alvarado-Ortega, J., Cantalice, K.M., Díaz-Cruz, J.A., Castañeda-Posadas, C., and ZavaletaVillareal, V. 2020a. Vertebrate fossils from the San José de Gracia quarry, a new Late Cretaceous marine fossil site in Puebla, Mexico. Boletín de la Sociedad Geológica Mexicana, 72(1):1-21. https://doi.org/10.18268/BSGM2020v72n1a160819

Alvarado-Ortega, J., Cantalice, K.M., Martínez-Melo, A., García-Barrera, P., Than-Marchese, B.A., Díaz-Cruz, J.A., and Barrientos-Lara, J.I. 2020b. Tzimol, a Campanian marine paleontological site of the Angostura Formation near Comitán, Chiapas, southeastern Mexico. Cretaceous Research, 107:1-16. https://doi.org/10.1016/j.cretres.2019.104279

Alvarado-Ortega, J., Garibay-Romero, L.M., Blanco-Piñón, A., González-Barba. G., Vega-Vera. F.J., and Centeno-García, E. 2006a. Los peces fósiles de la Formación Mexcala (Cretácico Superior) en el Estado de Guerrero, México. Revista Brasileira de Paleontologia, 93(3):261272.

Alvarado-Ortega, J., González Rodríguez, K.A., Blanco-Piñón, A., Espinosa-Arrubarrena, L., and Ovalles-Damián, E. 2006b. Mesozoic osteichthyans of Mexico, p. 169-207. In Vega, F.J., Nyborg, T.G., Perrilliat, M.C., Montellano Ballesteros, M., Cevallos Ferriz, S.R.S., and Quiroz Barroso, S.A. (eds.), Studies on Mexican Paleontology. Topics in Geobiology, 24. Springer, Dordrecht, the Netherlands.

Alvarado-Ortega, J., Ovalles-Damián, E., and Blanco-Piñón, A. 2009. The fossil fishes from the Sierra Madre Formation, Ocozocoautla, Chiapas, southern Mexico. Palaeontologia Electronica, 12.2.4A:1-22. palaeo-electronica.org/2009_2/168/index.html

Alvarado-Ortega, J. and Than-Marchese, B.A. 2012. A Cenomanian aipichthyoid fish (Teleostei, Acanthomorpha) from America, Zoqueichthys carolinae gen. and sp. nov. from El Chango quarry (Cintalapa Member, Sierra Madre Formation), Chiapas, Mexico. Revista Mexicana de Ciencias Geológicas, 29(3):735-748.

Alvarado-Ortega, J. and Than-Marchese, B.A. 2013. The first record of a North American Cenomanian Trachichthyidae fish (Acanthomorpha, Acanthopterygii), Pepemkay maya, gen. et sp. nov., from El Chango quarry (Sierra Madre Formation), Chiapas, Mexico. Journal of Vertebrate Paleontology, 33(1):48-57. https://doi.org/10.1080/02724634.2012.712585

Álvarez-Mena, A. 1975. Estratigrafía del Cretácico de la Región Central de Chiapas. Bachelor's Thesis, Instituto Politécnico Nacional, Escuela Superior de Ingeniería y Arquitectura, México.

Amaral, C.R., Alvarado-Ortega, J., and Brito, P.M. 2013. Sapperichthys gen. nov., a new gonorynchid from the Cenomanian of Chiapas, Mexico, p. 305-323. In Arratia, G., Shultze, H.-P., and Wilson, M.V.H. (eds.), Mesozoic Fishes V-Global Diversity and Evolution. Verlag Dr. Friedrich Pfiel, Munchen, Germany.

Arambourg, C. 1954. Les poissons crétacés du Jebel Tselfat (Maroc). Notes et Mémoires du Service Géologique, 118:1-188.

Bardet, N., Gheerbrant, E., Noubhani, A., Henri, C., Jouve, S., Bourdon, E., Pereda Suberbiola, X., Jalil, N.-E., Vincent, P., Houssaye, A., Sole, F., El Houssani Darif, K., Adnet, S., Rage, J.C., De Lapparent de Broin, F., Sudre, J., Bouya, B., Amaghzaz, M., and Meslouh, S. 2017. Les vertébrés des phosphates crétacés-paléogènes (72,1-47,8 Ma) du Maroc, p. 351-452. In Zourhi, S. (ed.), Paléontologie des Vertébrés du Maroc: état des connaissances. Mémoires de la Société Géologique de France, 180.

Beckett, H., Giles, S., and Friedman, M. 2017. Comparative anatomy of the gill skeleton of fossil Aulopiformes (Teleostei: Eurypterygii). Journal of Systematic Palaeontology, 16(14):12211245. https://doi.org/10.1080/14772019.2017.1387184

Bell, M.A. and Lloyd, G.T. 2015a. Strap: An R package for plotting phylogenies against stratigraphy and assessing their stratigraphic congruence. Palaeontology, 58(2):379-389. https://doi.org/10.1111/pala.12142 
Bell, M.A. and Lloyd, G.T. 2015b. Strap: An R package for plotting phylogenies against stratigraphy and assessing their stratigraphic congruence: A tutorial. Palaeontology, 58(2):379-389. https://doi.org/10.1111/pala.12142

Blanco-Piñón, A. 1998. Vallecillo Nuevo León: Yacimiento Fosilífero del Noreste de México. Master's Thesis. Facultad de Ciencias de la Tierra, Universidad Autónoma de Nuevo León, Linares.

Bogan, S. and Agnolin, F.L. 2010. Primera ictiofauna marina del Cretácico Superior (Formación Jaguel, Maastrichtiano) de la provincia de Río Negro, Argentina. Papéis Avulsos de Zoologia, 50(12):175-188. https://doi.org/10.1590/S0031-10492010001200001

Böse, E. 1905. Reseña acerca de la geología de Chiapas y Tabasco. Instituto Geológico de México, Boletín, 20:1-113.

Brazeau, M.D. 2011. Problematic character coding methods in morphology and their effects. Biological Journal of the Linnean Society, 104(3):489-498. https://doi.org/10.1111/j.10958312.2011.01755.x

Carbot-Chanona, G. 2015. La Colección Paleontológica de la SEMAHN: análisis preliminar. Lacandonia, 9(2):43-54.

Carbot-Chanona, G. and Than-Marchese, B.A. 2013. Presencia de Enchodus (Osteichthyes: Aulopiformes: Enchodontidae) en el Maastrichtiano (Cretácico tardío) de Chiapas, México. Paleontología Mexicana, 63(1):8-16.

Catalano, S.A., Ercoli, M.D., and Prevosti, F.J. 2014. The more, the better: the use of multiple landmark configurations to solve the phylogenetic relationships in musteloids. Systematic Biology, 64(2):294-306. https://doi.org/10.1093/sysbio/syu107

Catalano, S.A. and Goloboff, P.A. 2012. Simultaneously mapping and superimposing landmark configurations with parsimony as optimality criterion. Systematic Biology, 61(3):392-400. https://doi.org/10.1093/sysbio/syr119

Catalano, S.A. and Goloboff, P.A. 2018. A guide for the analysis of continuous and landmark characters in TNT (Tree Analysis using New Technologies). https://doi.org/10.13140/ RG.2.2.23797.27360

Catalano, S.A., Goloboff, P.A., and Giannini, N.P. 2010. Phylogenetic morphometrics (I): the use of landmark data in a phylogenetic framework. Cladistics, 26(5):539-549. https://doi.org/ 10.1111/j.1096-0031.2010.00302.x

Catalano, S.A. and Torres, A. 2016. Phylogenetic inference based on landmark data in 41 empirical data sets. Zoologica Scripta, 46(1):1-11. https://doi.org/10.1111/zsc.12186

Cavin, L. 1999. Occurrence of a juvenile teleost, Enchodus sp., in a fish gut content from the upper Cretaceous of Goulmima, Morocco. Special Papers in Palaeontology, 60:57-72.

Cavin, L., Alexopoulos, A., and Piuz, A. 2012. Late Cretaceous (Maastrichtian) ray-finned fishes from the island of Gavdos, southern Greece, with comments on the evolutionary history of the aulopiform teleost Enchodus. Bulletin de la Societe Geologique de France, 183(6):561572. https://doi.org/10.2113/gssgfbull.183.6.561

Chalifa, Y. 1996. New species of Enchodus (Aulopiformes: Enchodontidae) from the Northern Negev, Israel, with comments on evolutionary trends in the Enchodontoidei, p. 349-367. In Arratia, G. and Schultze, H.-P. (eds.), Mesozoic Fishes-Systematics and Paleoecology. Verlag Dr. Friedrich Pfeil, München, Germany.

Cicimurri, D.J. and Everhart, M.J. 2001. An elasmosaur with stomach contents and gastroliths from the Pierre Shale (Late Cretaceous) of Kansas. Transactions of the Kansas Academy of Science, 104(3):129-143. https://doi.org/10.1660/00228443(2001)104[0129:AEWSCA]2.0.CO;2

Coelho, P.M. 2004. Revisão Sistemática dos Enchodontidae (Euteleostei: Aulopiformes) do Brasil. M.Sc.Thesis. Universidade Federal do Rio de Janeiro, Rio de Janeiro, Brasil.

Cope, E.D. 1872. On the families of fishes of the Cretaceous formation of Kansas. Proceedings of the American Philosophical Society, 12(86):327-357.

Cope, E.D. 1874. Review of the Vertebrata of the Cretaceous Period found west of Mississippi River. Bulletin of the U.S. Geological and Geographical Survey, Territories, 1(2):3-48.

Davis, J.W. 1887. The fossil fishes of the Chalk of Mount Lebanon in Syria. Scientific Transactions of the Royal Dublin Society, 3:457-636.

Davis, M.P. and Fielitz, C. 2010. Estimating divergence times of lizardfishes and their allies (Euteleostei: Aulopiformes) and the timing of deep-sea adaptations. Molecular Phylogenetics and Evolution, 57(3):1194-1208. https://doi.org/10.1016/j.ympev.2010.09.003 
Díaz-Cruz, J.A. and Alvarado-Ortega, J. 2017. Los peces enchodóntidos de México. Paleontología Mexicana, 2:37.

Díaz-Cruz, J.A. and Alvarado-Ortega, J. 2018. The Late Cretaceous enchodontids (Enchodontidae: Aulopiformes) fishes from Mexico: new light into the evolution of Enchodontidae. 5th International Palaeontological Congress, Paris, France, p. 1038.

Díaz-Cruz, J.A., Alvarado-Ortega, J., and Bernard, E. 2019a. Phylogenetic implications of two enchodontids species (Enchodontidae: Aulopiformes) from the Middle East: researching on the global evolutive patterns of the enchodontid fishes. Paleontologia Mexicana, 5:24.

Díaz-Cruz, J.A., Alvarado-Ortega, J., and Carbot-Chanona, G. 2016. The Cenomanian short snout enchodontid fishes (Aulopifomes, Enchodontidae) from Sierra Madre Formation, Chiapas, southeastern Mexico. Cretaceous Research, 61:136-150. https://doi.org/10.1016/ j.cretres.2015.12.026

Díaz-Cruz, J.A., Alvarado-Ortega, J., and Carbot-Chanona, G. 2019b. Dagon avendanoi gen. and sp. nov., an Early Cenomanian Enchodontidae (Aulopiformes) fish from the El Chango quarry, Chiapas, southeastern Mexico. Journal of South American Earth Sciences, 91:272284. https://doi.org/10.1016/j.jsames.2019.01.014

Díaz-Cruz, J.A., Alvarado-Ortega, J., and Carbot-Chanona, G. 2019c. Corrigendum to "Dagon avendanoi gen. and sp. nov., an Early Cenomanian Enchodontidae (Aulopiformes) fish from the El Chango quarry, Chiapas, southeastern Mexico." Journal of South American Earth Sciences, 91:272-284. https://www.sciencedirect.com/science/article/pii/ S0895981119304183

Fielitz, C. 2004. The phylogenetic relationships of the †Enchodontidae (Teleostei: Aulopiformes), p. 619-634. In Arratia, G., Wilson, M.V.H., and Cloutier, R. (eds.), Recent Advances in the Origin and Early Radiation of Vertebrates. Verlag Dr. Friedrich Pfeil, München.

Fielitz, C. and González-Rodríguez, K.A. 2010. A New Species of Enchodus (Aulopiformes: Enchodontidae) from the Cretaceous (Albian to Cenomanian) of Zimapán, Hidalgo, México. Journal of Vertebrate Paleontology, 30(5):1343-1351. https://doi.org/10.1080/ 02724634.2010 .501438

Fitch, W. 1971. Toward defining the course of evolution: minimal change for a specific tree topology. Systematic Zoology, 20:406-416.

Forey, P.L., Yi, L., Patterson, C., and Davies, C.E. 2003. Fossil fishes from the Cenomanian (Upper Cretaceous) of Namoura, Lebanon. Journal of Systematic Palaeontology, 1(4):227330. https://doi.org/10.1017/S147720190300107X

Friedman, M., Beckett, H.T., Close, R.A., and Johanson, Z. 2016. The English Chalk and London Clay: Two remarkable British bony fish lagerstätten. Geological Society Special Publication, 430(1):165-200. https://doi.org/10.1144/SP430.18

Garcia, G.G., Garcia, A.J.V., and Henriques, M.H.P. 2018. Palynology of the Morro do Chaves Formation (Lower Cretaceous), Sergipe Alagoas Basin, NE Brazil: paleoenvironmental implications for the early history of the South Atlantic. Cretaceous Research, 90:7-20. https:/ /doi.org/10.1016/j.cretres.2018.03.029

Giersch, S. 2014. Die Knochenfische der Oberkreidezeit in Nordostmexiko: Beschreibung, Systematik, Vergesellschaftung, Paläobiogeographie und Paläoökologie. PhD Thesis, Ruprecht-Karls-Universität Heidelberg, Germany.

Giersch, S., Frey, E., Stinnesbeck, W., and González-González, A.H. 2008. Fossil fish assemblages of northeastern Mexico: new evidence of mid Cretaceous Actinopterygian radiation, p. 43-45. In Krempaská, Z. (ed.), 6th Meeting of the European Association of Vertebrate Paleontology, Museum of Spiš, Spišská Nová Ves, Slovak Republic.

Goloboff, P.A. and Catalano, S.A. 2016. TNT version 1.5, including a full implementation of phylogenetic morphometrics. Cladistics, 32(3):221-238.

Goloboff, P.A., Torres, A., and Arias, J.S. 2018. Weighted parsimony outperforms other methods of phylogenetic inference under models appropriate for morphology. Cladistics, 34(4):407437. https://doi.org/10.1111/cla.12205

González, A.J. 1963. Levantamiento del Área San Cristóbal-Bachajón. Petróleos Mexicanos, Zona Sur, Informe Geológico, 498:1-59. (unpublished report)

González-Barba, G. and Espinosa-Chávez, B. 2005. Cenomanian-Turonian fish fauna from the Boquillas Formation at Jaboncillos, north-west Coahuila, Mexico, p. 105-107. In PoyatoAriza, F.J. (ed.), Fourth International Meeting on Mesozoic Fishes - Systematics, Homology, and Nomenclature, Maraflores de la Sierra, Madrid, España. Extended Abstracts. Servicio de Publicaciones de la Universidad Autónoma de Madrid/UAM Ediciones, Spain. 
González-Ramírez, I., Calvillo-Canadell, L., and Cevallos-Ferriz, S.R.S. 2013. Coníferas cupresaceas fósiles de El Chango, Chiapas (Aptiano). Paleontología Mexicana, 63(1):2631.

González-Rodríguez, K.A., Fielitz, C., Bravo-Cuevas, V.M., and Baños-Rodríguez, R.E. 2016. Cretaceous osteichthyan fish assemblages from Mexico. New Mexico Museum of Natural History and Science Bulletin, 71:1-14.

Goody, P.C. 1968. The skull of Enchodus faujasi from the Maastricht of southern Holland. Proceedings of the Koninklijke Nederlandse Akademie van Wetenschappen, B71:209-231.

Goody, P.C. 1969. The relationships of certain Upper Cretaceous teleosts, with special reference to the myctophoids. Bulletin of the British Museum (Natural History) Geology Supplement, 7:1-255.

Goody, P.C. 1976. Enchodus (Teleostei: Enchodontidae) from the Upper Cretaceous Pierre Shale of Wyoming and South Dakota with an evaluation of the North American enchodontid species. Palaeontographica Abteilung, A152:91-112.

Gouiric-Cavalli, S., Cione, A.L., Pérez, L.M., Iribarme, M., Allcca, M., and Poiré, D.G. 2016. Primer Registro del pez cretácico Enchodus. XVIII Congreso Peruano de Geología, Lima, Perú, p. 1-3.

Green, W.R. 1913. A description of the specimens of the teleostean genus Enchodus in the University of Kansas Museum. Kansas University Science Bulletin, 7(2):71-107.

Guerrero-Márquez, G., Calvillo-Canadell, L., Cevallos-Ferriz, S. R., and Avendaño Gil, J. 2013. Angiospermas cretácicas de la localidad "El Chango", Chiapas, México. Paleontología Mexicana, 63(1):32-39.

Guinot, D., Carbot-Chanona, G., and Vega, F.J. 2019. Archaeochiapasidae n. fam., a new early Cenomanian brachyuran family from Chiapas, Mexico, new insights on Lecythocaridae Schweitzer \& Feldmann, 2009, and phylogenetic implications. Geodiversitas, 41(7):285-322. https://doi.org/10.5252/geodiversitas2019v41a7

Günther, A. 1873. XXXI.- Report on a collection of fishes from China. Journal of Natural History, 12(69):239-250.

Hay, O.P. 1903. On certain genera and species of North American Cretaceous actinopterous fishes. Bulletin of the American Museum of Natural History, 19(1):1-9.

Heckel, J.J. 1850. Beiträge zur Kenntniss der fossilen Fische Oesterreichs. Denkschriften der kaiserlichen Akademie der Wissenschaften, math.-naturwiss. Classe, 1:201-242.

Höhna, S., Landis, M.J., and Heath, T.A. 2017. Phylogenetic inference using RevBayes. Current Protocols in Bioinformatics, 57(1):6-16. https://doi.org/10.1002/cpbi.22

Höhna, S., Landis, M.J., Heath, T.A., Boussau, B., Lartillot, N., Moore, B.R., Huelsenbeck, J.P., and Ronquist, F. 2016. RevBayes: Bayesian phylogenetic inference using graphical models and an interactive model-specification language. Systematic Biology, 65(4):726-736. https:// doi.org/10.1093/sysbio/syw021

Holloway, W.L., Claeson, K.M., Sallam, H.M., El-Sayed, S., Kora, M., Sertich, J.J.-W., and O'Connor, P.M. 2017. A new species of the neopterygian fish Enchodus from the Duwi Formation, Campanian, Late Cretaceous, Western Desert, central Egypt. Acta Palaeontologica Polonica, 62(3):603-611. https://doi.org/10.4202/app.00331.2016

Huelsenbeck, J.P. 1994. Comparing the stratigraphic record to estimates of phylogeny. Paleobiology, 20(4):470-483.

Huerta-Vergara, A.R., Calvillo-Canadell, L., Cevallos-Ferriz, S.R.S., and Silva-Pineda, A. 2013. Pinaceae en el Cretácico del norte y sur de México: complemento a su escaso registro fósil. Paleontología Mexicana, 63(1):66-78.

Kaddumi, H.F. 2009. A new species of large Enchodus fishes (Aulopiformes: Enchodontidae) from the late Maastrichtian of Harrana, p. 204-214. In Kaddumi, H.F., Fossils of the Harrana Fauna and the Adjacent Areas. Eternal River Museum of Natural History, Amman, Jordan.

Kramberger, D.G. 1895. De piscibus fossilibus Comeni, Mrzleci, Lesinae et M. Libanonis. Djela Jugoslavenska Akademija Znanosti, I Umjetnosti, Zagreb, 16:1-67.

Kriwet, J. 2003. Lancetfish teeth (Neoteleostei, Alepisauroidei) from the Early Cretaceous of Alcaine, NE Spain. Lethaia, 36(4):323-332. https://doi.org/10.1080/00241160310006484

Leidy, J. 1857. Notices of some remains of extinct fishes. Proceedings of the Academy of Natural Sciences of Philadelphia, 1857:167-168.

Lowe, R.T. 1833. Description of Alepisaurus, a new genus of fishes. Proceedings of the Zoological Society of London, 1:104. 
Maddison, W.P. and Maddison, D.R. 2001. Mesquite: a Modular System for Evolutionary Analysis, Version 3.61. https://www.mesquiteproject.org/

Maisey, J.G. 1996. Discovering Fossil Fishes. Henry Holt and Company, New York.

Maldonado-Koerdell, M. 1956. Peces fósiles de México, III. Nota preliminar sobre los peces del Turoniano Superior de Xilitla, San Luis Potosi (México). Ciencia, 19:1-9.

Mantell, G. 1822. The Fossils of the South Downs; or Illustrations of the Geology of Sussex. Lupton Relfe, London.

Moreno-Bedmar, J.A., Latil, J.-L., Villanueva-Amadoz, U., Calvillo-Canadell, L., and CevallosFerriz, S.R.S. 2014. Ammonite age-calibration of the El Chango Fossil-Lagerstätte, Chiapas state (SE Mexico). Journal of South American Earth Sciences, 56:447-453. https://doi.org/ 10.1016/j.jsames.2014.09.022

Nixon, K.C. 2002. Winclada-ASADO 1.61. Computer Software and Documentation.

Ovalles-Damián, E., Alvarado-Ortega, J., and Blanco-Piñón, A. 2006. Los peces fósiles del Cretácico inferior de Ocozocoautla, Chiapas. Memorias del X Congreso Nacional de Paleontología, Sociedad Mexicana de Paleontología, México, p. 6.

Palci, A. and Lee, M.S.Y. 2018. Geometric morphometrics, homology and cladistics: review and recommendations. Cladistics, 35(2):230-242. https://doi.org/10.1111/cla.12340

Perrard, A., López-Osorio, F., and Carpenter, J.M. 2015. Phylogeny, landmark analysis and the use of wing venation to study the evolution of social wasps (Hymenoptera: Vespidae: Vespinae). Cladistics, 32(4):406-425. https://doi.org/10.1111/cla.12138

Pictet, F.J. 1850. Description de Guelques Poissons Fossiles du Mont Liban. J-K Fick, Geneve.

Porras-Múzquiz, H. and Alvarado-Ortega, J. 2011. Sobre la ocurrencia de Enchodus petrosus Cope en el Cretácico tardío de Múzquiz, Coahuila, México. XII Congreso Nacional de Paleontología, Sociedad Mexicana de Paleontología, Benemérita Universidad Autónoma de Puebla, p. 113.

Porras-Múzquiz, H.G., Díaz-Cruz, J.A., Alvarado-Ortega, J., and Cantalice, K.M. 2019. Evidencia de interacción depredador-presa en peces del género Enchodus (Enchodontidae: Aulopiformes) de localidades del Cretácico Superior Coahuila, Norte de México PorrasMúzquiz. Paleontología Mexicana, 5:116.

Puttick, M.N., O'Reilly, J.E., Pisani, D., and Donoghue, P.C.J. 2018. Probabilistic methods outperform parsimony in the phylogenetic analysis of data simulated without a probabilistic model. Palaeontology, 62(1):1-17. https://doi.org/10.1111/pala.12388

Quezada-Muñetón, J.Q. 1987. El Cretácico medio-Superior y el límite Cretácico SuperiorTerciario inferior en la Sierra de Chiapas. Boletín de la Asociación Mexicana de Geologos Petroleros, 39(1):1-98.

Raab, M. and Chalifa, Y. 1987. A new enchodontid fish genus from the upper Cenomanian of Jerusalem, Israel. Palaentology, 30:717-731.

Rambaut, A., Drummond, A.J., Xie, D., Baele, G., and Suchard, M.A. 2018. Posterior summarization in Bayesian phylogenetics using Tracer 1.7. Systematic Biology, 67(5):901904. https://doi.org/10.1093/sysbio/syy032

Rohlf, F.J. 2005. tpsDig, digitize landmarks and outlines. Department of Ecology and Evolution, State University of New York at Stony Brook, Stony Brook, New York.

Rosen, D.E. 1973. Interrelationships of higher euteleostean fishes, p. 397-513. In Greenwood, P.H., Miles, R.S., and Patterson, C. (eds.), Interrelationships of Fishes. Zoological Journal of the Linnean Society Supplement 1.

Salas, G.P. 1949. El Cretácico de la Cuenca de Macuspana y su correlación. Boletín de la Sociedad Geológica Mexicana, 14:47-65.

Sánchez-Montes de Oca, R. 1969. Estratigrafía y paleogeografía del Mesozoico de la Sierra del Sur: Instituto Mexicano del Petróleo. Seminario Sobre Exploración Petrolera, Mesa 4, Capítulo 5.

Sánchez-Montes de Oca, R. 1973. Proyecto Mesozoico Arrecifal, Sierra de Chiapas: México, Petróleos Mexicanos, Zona Sur. Informe Geológico 581. (unpublished report)

Schein, J.P., Parris, D.C., Poole, J.C., and Lacovara, K.J. 2013. A nearly complete skull of Enchodus ferox (Actinopterygii, Aulopiformes) from the Upper Cretaceous Ripley Formation of Lowndes County, Alabama. Bulletin of the Alabama Museum of Natural History, 31(1):7883.

Siegel, F.A. and Benson, R.H. 1982. A robust comparison of biological shapes. Biometrics, 38(2):341-350. 
Silva-Santos, R. and Salgado, S. 1969. Enchodus longipectoralis (Schaeffer), um Teleostei do Cretáceo de Sergipe. Anais da Academia Brasileira de Ciências, 41(3):381-392.

Silva, H.M.A. and Gallo, V. 2007. Parsimony analysis of endemicity of enchodontoid fishes from the Cenomanian. Carnets de Géologie, 1:1-8.

Silva, H.M.A. and Gallo, V. 2011. Taxonomic review and phylogenetic analysis of Enchodontoidei (Teleostei: Aulopiformes). Anais da Academia Brasileira de Ciencias, 83(2):483-511. https:// doi.org/10.1590/S0001-37652011000200010

Simões, T.R., Caldwell, M.W., Palci, A., and Nydam, R.L. 2017. Giant taxon-character matrices: quality of character constructions remains critical regardless of size. Cladistics, 33(2):198219. https://doi.org/10.1111/cla.12163

Steele, D.R. 1986. Contributions to the stratigraphy of Sierra Madre Limestone (Cretaceous) of Chiapas, Part 1. Physical stratigraphy and petrology of the Cretaceous Sierra Madre Limestone, westcentral Chiapas: Instituto de Geología, Boletín, 102:1-101.

Stewart, A. 1898. A preliminary description of seven new species of fish from the Cretaceous of Kansas. Kansas University Quarterly, 7:189-196.

Stewart, J.D. and Carpenter, K. 1990. Examples of vertebrate predation on cephalopods in the Late Cretaceous of the Western Interior, p. 203-206. In Boucot, A.J. (ed.), Evolutionary Paleobiology of Behavior and Coevolution. Elsevier, Amsterdam.

Toombs, H.A. and Rixon, A.E. 1950. The use of plastics in the "Transfer Method" of preparing fossils. The Museums Journal, 50(5):105-107.

Toombs, H.A. and Rixon, A.E. 1959. The use of acids in the preparation of vertebrate fossils. Curator: The Museum Journal, 2(4):304-312.

Uyeno, T. and Minakawa, T. 1983. A new enchodontoid fish of the genus Eurypholis from Cretaceous of Japan. Bulletin of the National Science Museum. Series C, 9(2):79-83.

Vega, F.J., Álvarez, F., and Carbot-Chanona, G. 2007. Albian penaeoidea [sic] (Decapoda: Dendrobranchiata) from Chiapas, Southern Mexico. Memorie della Societá Italiana di Scienze Naturali e del Museo Civico di Storia Naturale di Milano, 35(2):6-8.

Vernygora, O., Murray, A.M., Luque, J., Ruge, M.L.P., and Fonseca, M.E.P. 2017. A new Cretaceous dercetid fish (Neoteleostei: Aulopiformes) from the Turonian of Colombia. Journal of Systematic Palaeontology, 16(12):1057-1071. https://doi.org/10.1080/ 14772019.2017.1391884

von der Marck, W. 1858. Ueber einige Wirbelthiere, Crustaceen und Cephalopoden der westfälishcen Kreide. Zeitschrift der deutschen geologischen Gesellschaft, Berlin, 10:231271.

von der Marck, W. 1863. Fossile Fische, Krebse und Pflanzen aus dem Plattenkalk der jüngsten Kreide in Westphalen. Palaeontographica, 11:1-83.

Waite, L.E. 1986, Contributions to the stratigraphy of Sierra Madre Limestone (Cretaceous) of Chiapas, Part 2, Biostratigraphy and paleoenvironmental analysis of the Sierra Madre Limestone (Cretaceous), Chiapas. Instituto de Geología, Boletín, 102:103-245.

Wiebe, W.A. 1925, Geology of southern Mexico oil fields. Pan-American Geologist, 94:121-138.

Wilson, M.V. and Chalifa, Y. 1989. Fossil marine actinopterygian fishes from the Kaskapau Formation (Upper Cretaceous: Turonian) near Watino, Alberta. Canadian Journal of Earth Sciences, 26(12):2604-2620. https://doi.org/10.1139/e89-222

Woodward, A.S. 1901. Catalogue of the fossil fishes in the British Museum (Natural History). Part IV. Containing the actinopteryigian Teleostomi of the suborders Isospondyli (in part), Ostariophysi, Apodes, Percesoces, Hemibranchii, Acanthopterygii, and Anacanthini. British Museum (Natural History), London.

Yabumoto, Y., Uyeno, T. 1994. Late Mesozoic and Cenozoic fish faunas of Japan. The Island Arc, 3(4):255-269. 


\section{APPENDIX I}

This appendix contains all the data matrices used in the phylogenetic study of Vegrandichthys coitecus gen. et sp. nov. Here, we present the matrices in the order they appear in the main manuscript. (PDF file available for zipped download at https://palaeo-electronica.org/content/2020/ 3063-a-long-snout-enchodontid-fish.)

\section{APPENDIX II}

This appendix presents the modifications made to some characters reported in previous works, it also shows the complete list of the characters used in the phylogenetic analyses, highlighting those that were not considered or included due to be phylogenetically uninformative (autoapomorphic or invariant). Also, it is possible to find the matrices employed in the phylogenetic exercises and the complete phylogenies obtained. (PDF file available for zipped download at https:// palaeo-electronica.org/content/2020/3063-a-long-snout-enchodontid-fish.) 